\title{
Pomlp, a fission yeast protein kinase that provides positional information for both polarized growth and cytokinesis
}

\author{
Jürg Bähler ${ }^{1}$ and John R. Pringle ${ }^{2}$ \\ Department of Biology, University of N orth Carolina, Chapel Hill, N orth Carolina 27599-3280 USA
}

\begin{abstract}
Schizosaccharomyces pombe cells have a well-defined pattem of polarized growth at the cell ends during interphase and divide symmetrically into two equal-sized daughter cells. We identified a gene, pom1, that provides positional information for both growth and division in S. pombe. pom 1 mutants form functioning growth zones and division septa but show several abnormalities: (1) After division, cells initiate growth with equal frequencies from either the old or the new end; (2) most cells never switch to bipolar growth but instead grow exclusively at the randomly chosen end; (3) some cells mislocalize their growth axis altogether, leading to the formation of angled and branched cells; and (4) many cells misplace and/or misorient their septa, leading to asymmetric cell division. pom 1 encodes a putative protein kinase that is concentrated at the new cell end during interphase, at both cell ends during mitosis, and at the septation site after mitosis. Small amounts of Pomlp are also found at the old cell end during interphase and associated with the actin ring during mitosis. Pomlp localization to the cell ends is independent of actin but requires microtubules and Tealp. pom1 mutations are synthetically lethal with several other mutations that affect cytokinesis and/or the actin or microtubule cytoskeleton. Thus, Pomlp may position the growth and cytokinesis machineries by interaction with both the actin and microtubule cytoskeletons.
\end{abstract}

[Key Words: S. pombe; morphogenesis; polarity; actin; microtubules; cell division]

Received October 22, 1997; revised version accepted March 2, 1998.

The generation of a specific cell shape and three-dimensional organization is crucial for cell function in both unicellular and multicellular organisms. A central aspect of cellular morphogenesis is polarization of the cell along an appropriate axis. Polarization depends on positional information within the cell and is critical for both cell division and development (Strome 1993; Lehmann 1995; Drubin and Nelson 1996). The mechanisms that generate and maintain cell polarity are not yet well understood, but they presumably involve positional signals from within or outside the cell, signal transduction elements, and the cytoskeleton. For example, in the budding yeast Saccharomyces cerevisiae, polarization of the cytoskel eton toward the bud site involves both cortical positional markers and GTPase signaling modules that communicate the positional information to the cytoskeleton (Pringle et al. 1995; Drubin and Nelson 1996).

In the fission yeast Schizosaccharomyces pombe, positional information is required both for polarized

\footnotetext{
${ }^{1}$ Present address: Imperial Cancer Research Fund, Cell Cycle Laboratory, London, WC2A 3PX UK.

${ }^{2}$ Corresponding author.

E-MAIL jpringle@email.unc.echu; FAX (919) 962-0320.
}

growth at the cell ends and for proper positioning of the centrally located plane of cell division. S. pombe cells grow as cylindrical rods of constant diameter by elongating at the cell ends. After cell division, both daughter cells initiate polarized growth by el ongating exclusively at the end that existed in the mother cell prior to division (the old end). In early $\mathrm{G}_{2}$ phase, the end generated by the preceding cell division (the new end) al so begins to grow. This transition from unipolar to bipolar growth is known as new end take off (NETO; M itchison and N urse 1985). After mitosis, cytokinesis and septum formation occur at a site that is normally midway between the cell ends. The sites of cell growth and division are reflected by the distribution of the actin cytoskel eton ( $M$ arks and Hyams 1985; Marks et al. 1986). During interphase, Factin patches are concentrated at the growing cell end(s). At mitosis, cell elongation ceases, and actin redistributes to the cell center to form a cortical ring, and later adjacent patches, in preparation for division. After division, actin relocates to the old ends of the two daughter cells, where polarized growth is reinitiated.

The microtubule cytoskeleton also appears to be involved in the positioning of polarized growth in S. pombe: Mutations in tubulin genes or treatment with microtubule-disrupting drugs leads to the formation of 
bent and/or branched cells (Umesono et al. 1983; Hiraoka et al. 1984; Y affe et al. 1996). During interphase, cytoplasmic microtubules are organized longitudinally in the cell, with many appearing to run from end to end (Hagan and Hyams 1988). At the onset of mitosis, these microtubules are replaced by spindle microtubules, and, after nuclear division, new cytopl asmi c microtubules are formed from two microtubule-organizing centers at the cell center.

Recent genetic analyses of morphogenesis in S. pombe have identified several interesting types of mutants (Snell and Nurse 1993, 1994; N urse 1994; Verde et al. 1995). For example, the ban and tea mutants are defective in the orientation of growth polarization; they can still polarize their growth machinery, but they form bent and/or T-shaped cells. Recently, M ata and N urse (1997) have reported that Tealp is directed by microtubules to the two cell ends, where it may act as a positional marker for the growth machinery. In contrast, the products of the midl (or dmfl) and pos genes are involved in determining the site of cell division. Mutants defective in these genes place septa at seemingly random positions and orientations, rather than at the cell center (Chang et al. 1996; Edamatsu and Toyoshima 1996; Sohrmann et al. 1996). Midlp localizes to the nucleus during interphase but forms a central ring at the cell cortex at mitosis; this ring might direct the cell division machinery to the cell center (Sohrmann et al. 1996).

In this report, we describe a novel gene, pom1, that encodes a predicted protein kinase that is involved in selecting the sites for both polarized growth and cell division in $\mathrm{S}$. pombe.

\section{Results}

Isolation of morphogenetic mutants

To identify S. pombe mutants with defects in morphogenesis, 7100 individual clones of mutagenized cells were screened by fluorescence microscopy as described in $\mathrm{M}$ aterials and $\mathrm{M}$ ethods. Forty mutants were identified that had interesting morphogenetic phenotypes caused by single mutations. Some of these mutants had phenotypes similar to those of previously described mutants, such as the formation of round, bent, or branched cells (see introductory section). Among these, six mutants that formed $\mathrm{T}$-shaped cells all proved to contain mutations in the previously described tea1 and tea2 genes (data not shown). Other mutants showed novel alterations of cell shape, septum formation, and/or cell-wall deposition. One mutant harbored a recessive mutation that we named pom1-1 (polarity misplaced); it showed defects in the positioning and orientation of division septa, as well as a few angled and T-shaped cells (Fig. 1A). The abnormal septum localization in the pom1-1 mutant resembled that of mid1 mutants (Chang et al . 1996; Sohrmann et al. 1996), but pom1-1 segregated independently of midl as well as of various other mutations affecting morphogenesis or cytokinesis, including teal, tea2, ban1, ban2, ban3, and ban4 (data not shown). The remainder of this report describes our analysis of the poml gene and its product.

\section{Cloning of pom1, a novel protein kinase gene}

To clone the gene defined by the pom1-1 mutation, we exploited the synthetic lethality of the pom1-1 dmf1-6 and pom1-1 cdc14-118 double mutants (see below and $M$ aterials and M ethods). Several plasmids with overlapping inserts rescued the viability of both double mutants as well as the morphological phenotypes of the pom1-1 single mutant. Partial sequencing revealed that the inserts were derived from a region near cdc25 on chromosome I that had been sequenced as part of the $S$. pombe genome project (cosmid C2F7; EMBL/GenBank/DDBJ accession no. Z50142). Crossing of pom1-1 (JB99) and cdc25-22 (JB20) strains showed that the two genes are linked (26 wild-type segregants among 460 segregants analyzed), suggesting that the isolated plasmids indeed contained poml and not a multicopy suppressor. Subcloning experiments showed that ORF SPAC2F7.03C was responsible for the rescue of pom1-1 (data not shown). This ORF was deleted by use of a PCR-generated fragment containing the ura $4^{+}$marker (see $M$ aterials and $M$ ethods). The phenotype of the resulting pom1- $\Delta 1$ mutant was indistinguishable from that of pom1-1 (see below), and pom1- $\Delta 1$ did not complement pom1-1 in a diploid strain (data not shown). Thus, SPAC2F7.03C is poml.

poml encodes a predicted protein of 1087 amino acids with a putative protein kinase catalytic domain near its carboxyl terminus (Fig. 2). This domain shows all 12 of the major conserved protein kinase subdomains (Hanks and Hunter 1995), including an ATP-binding site (amino acids 705-728). No other significant sequence motifs have been detected in Pomlp. poml does not contain any consensus splicing sites, suggesting that it has no introns, a conclusion supported by the sequences of partial cDN A clones (see M aterials and M ethods). The closest Pom1p homolog found in the databases was another predicted S. pombe protein kinase (accession no. Q 09815; SPAC 16C 9.07). The two proteins are 55\% identical in their kinase domains but otherwise share only a short region of homology immediately upstream of the kinase domains (33\% identity between amino aci ds 592698 of Pom1p and the corresponding region in the SPAC16C9.07 product). Other protein kinases with strong homology to Pom1p are rat Dyrk (Kentrup et al. 1996), human Dyrk2 and Dyrk3 (accession nos. Y 13493 and $Y$ 12735), the Caenorhabditis el egans F49E11. 1 product (accession no. Z70308), S. cerevisiae Yak1p (Garrett and Broach 1989), and the Drosophila and human M inibrains (Tejedor et al. 1995; Smith et al. 1997), which show $43 \%$ to $52 \%$ identity to Pomlp in their kinase domains. These proteins belong to an emerging novel family of protein kinases with potential dual specificity (Kentrup et al. 1996). Minibrain is involved in postembryonic neurogenesis and is implicated in learning defects associated with Down Syndrome (Tejedor et al. 1995; Smith et al. 1997; and references cited therein). 


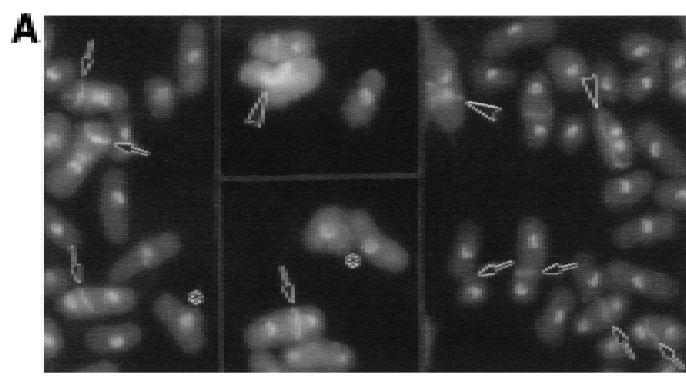

B wt

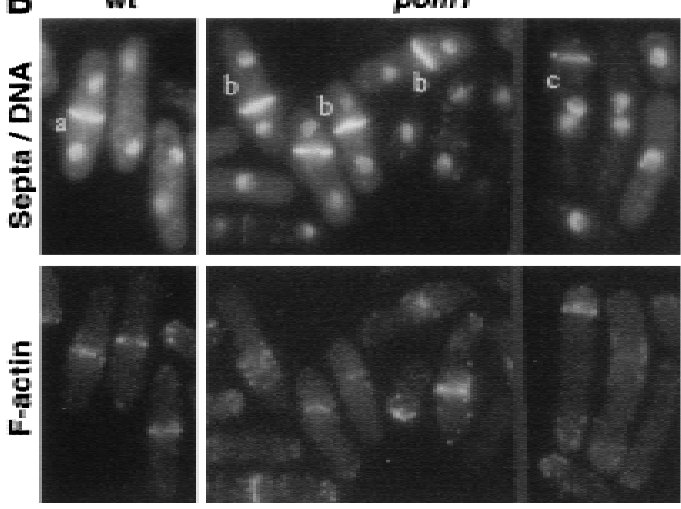

C

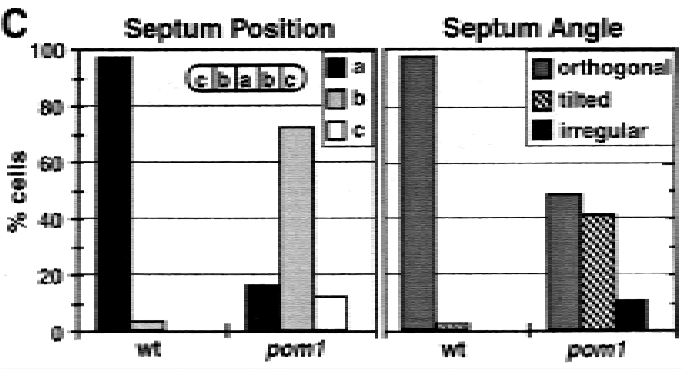

D

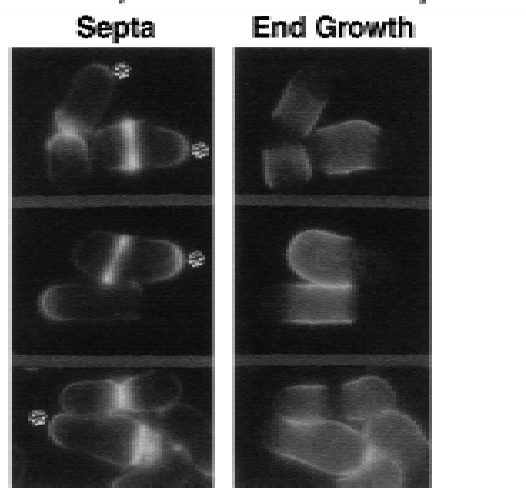

Outside the kinase domains, only Dyrk2, Dyrk3, the F49E11.1 product, and M inibrain show any homology to Pom1p (31\% to $47 \%$ identity over $29-73$ amino acids immediately upstream of the kinase domain). N otably, no homology other than to the kinase domain was found with any protein predicted by the S. cerevisiae genome sequence.

Mislocalization and misorientation of septa in poml mutant cells

pom1- $\Delta 1$ mutants (strains JB109 and JB110) are viable at temperatures from $20^{\circ} \mathrm{C}$ to $36^{\circ} \mathrm{C}$ and showed no obvious
Figure 1. (A) Abnormalities in cell shape and cell division in pom1-1 mutant cells. Strain JB100 cells growing exponentially at $30^{\circ} \mathrm{C}$ were stained with Calcofluor and bisBenzimide to visualize septa and DNA. (Asterisks) Cells with branched or angled growth; (arrows) cells with septa in abnormal positions and/or orientations; (arrowheads) cells with longitudinal or irregular septa. (B-D) Abnormal septum placement in pom1- $\Delta 1$ mutant cells. (B) Cells of wild-type strain 972 (left panels) and pom1- $\Delta 1$ strain JB110 (right panels) growing exponentially at $36^{\circ} \mathrm{C}$ were stained with Calcofluor and bisBenzimide (upper panels) and with rhodamine-phalloidin to visualize F-actin (lower panels). (a, b, and c) Cells with different degrees of septum misplacement, as used for the quantitative analysis in C. (C) Septation patterns were scored in $>300$ cells from each culture shown in B. (Left) Septum position was scored relative to the long axis of the cell as divided into five equal compartments (see examples in B). (Right) Septum angle was scored relative to the long axis of the cell. Septa with angles of $80^{\circ}$ to $90^{\circ}$ were designated as orthogonal and septa with smaller angles as tilted. Septa that looked very aberrant (e.g., consisting of several sheets) or were placed longitudinally in the cell (see examples in A) were scored as irregular. (D) JB110 cells growing exponentially at $30^{\circ} \mathrm{C}$ were treated with FITC-conjugated lectin to stain their cell walls, then washed and grown for $45 \mathrm{~min}$ before staining with Calcofluor (left). The cell ends that had grown during the $45 \mathrm{~min}$ after labeling with lectin can be identified by their unlabeled surface (right) and are marked with asterisks (left).

defects in mating, meiosis, or sporulation; they did, however, have generation times $\sim 20 \%$ longer than those of wild type (data not shown). As with the pom1-1 mutant, the most obvious phenotype of pom1- $\Delta 1$ cells was fre quent misplacement and/or misorientation of the septum (Fig. 1B,C). The misplaced septa colocal ized with equival ently misplaced actin rings (Fig. 1B), as expected from the role of actin in septation. To investigate the positioning of the misplaced septa relative to the cell ends, we visualized the growing ends and septa simultaneously (see Materials and Methods). This reveal ed a strong bias in septum positioning: Among 122 cells with asymmetrical ly positioned septa, 119 had the septum positioned closer to the nongrowing (or less extensively growing) end (as illustrated in Fig. 1D). This bias was al so evident in time-lapse studies (Fig. 3, 43 to $263 \mathrm{~min}$ ).

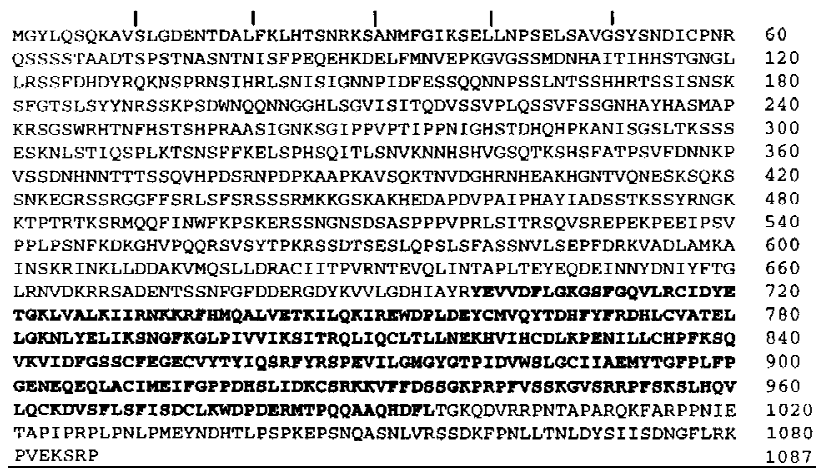

Figure 2. Predicted sequence of Pom1p (accession no. Z50142). The kinase domain (amino acids 699-995) is shown in boldface type. 

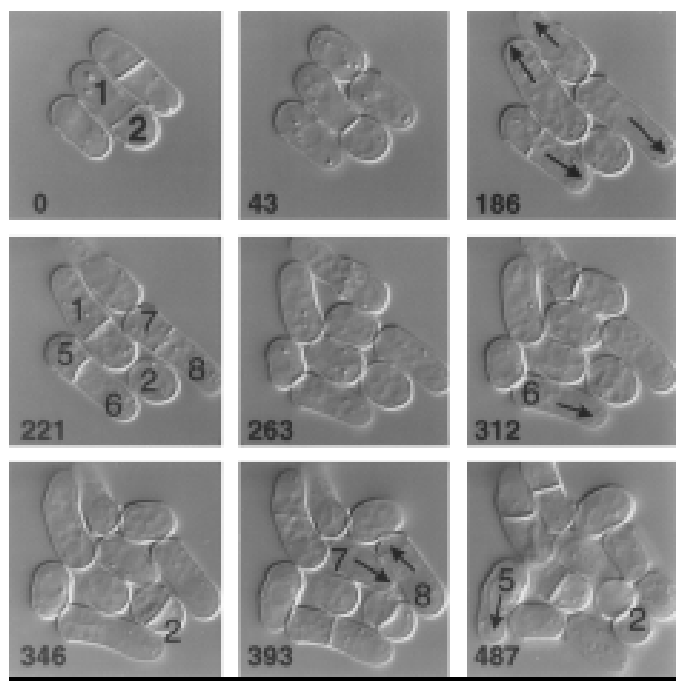

Figure 3. Time-lapse analysis of the growth of a pom1-1 strain. JB100 cells growing at room temperature in YE medium were observed by DIC microscopy (see M aterials and M ethods). The times in minutes since the beginning of observation are indicated. Individual cells are numbered for reference in the text. (Arrows) Growing cell ends.

In contrast to the septa, nuclei appeared to be positi oned normally at the cell center during interphase, and to divide normally, in pom 1 mutant cells (Figs. 1A,B and 5C). Time-lapse observations (Fig. 3) suggested that the mislocalized and misoriented septa are generally functional for cell division, a conclusion supported by the observations that the percentages of cells with visible septa or with actin rings in the pom 1 mutants are similar to those in wild type (Fig. 4B and data not shown). However, anucl eate cells were not observed in the pom 1 mutants, suggesting that septa forming anucl eate compartments (e.g., Fig. 1B, cell c) may not be cleaved.

The time-lapse studies also showed that the asymmetric cell divisions can lead to a pronounced asynchrony in the subsequent cell divisions of the unequal-sized daughter cells (e.g., Fig. 3, cells 1 and 2). On average, however, pom 1 mutant cells are only $\sim 10 \%$ shorter than wild-type cells at cell division (data not shown), suggesting that cell size regulation is largely normal.

\section{Mislocalization of polarized growth in pom1 mutant} cells

Wild-type cells grow initially at one end but later (after NETO; see introductory section) grow at both ends. In contrast, cell-surface staining (Fig. 1D) and time-lapse observations (Fig. 3, arrows) suggested that pom1 mutant cells grow only at one end until septum formation. To explore further the apparent defect in the switch to bipolar growth, we examined the organization of actin in pom1 mutant cells. Long wild-type cells consistently have F-actin patches concentrated at both cell ends (Fig. 4A,B). In contrast, long pom 1 mutant cells showed predominantly unipolar actin staining (Fig. 4A,B). To ask whether the switch to bipolar growth was blocked or merely del ayed in the cell cycle, we used a temperature sensitive cdc25 mutation. The cdc25 single mutant be comes arrested in $\mathrm{G}_{2}$ after NETO (M itchison and N urse 1985), as reflected by the localization of actin to both ends of the cells (Fig. 4A,B). In contrast, a pom1 cdc25 double mutant showed unipolar actin localization (Fig. $4 A, B)$, suggesting that the switch to bipolar growth is permanently blocked by the loss of Pomlp function.

The time-lapse studies reveal ed another interesting aspect of the pom 1 mutant phenotype. In wild-type cells, it is always the old end that initiates growth after cell division. In contrast, in pom 1 mutant cells, either the old end (Fig. 3, cell 6, 263-312 $\mathrm{min}$ ) or the new end (Fig. 3, cells 5, 7, and 8, 346-487 $\mathrm{min}$ ) could initiate growth. These few examples al so suggest that there is no necessary correl ation between the ends sel ected for growth by the two daughter cells generated by one cell division.

To explore further this apparent defect in the selection of the growth pole, we stained cdc10 and poml cdc10 mutant cells with Cal cofluor, which reveals the division scars as weakly stained regions of the cell wall (Mitchison and N urse 1985). At restrictive temperature, cdc10 mutants arrest in $\mathrm{G}_{1}$ prior to NETO (Mitchison and N urse 1985); thus, actin polarization (Fig. 4B) and cell growth occur only at the old end, and the most recent division scar is seen as a dark hemisphere at the new cell end (Fig. 4C,D). The pom1 cdc10 double mutant also polarized to just one end (Fig. 4B); however, that end could be either the old end (division scar thus seen at the new end) or the new end (division scar thus displaced from the new end by growth at that end), in approximately equal frequency (Fig. 4C,D). Similar results were obtai ned with cdc 25 and pom 1 cdc 25 mutant strains. As noted above, the cdc25 single mutant undergoes NETO, so that the division scar is invariably displaced from the new end (Fig. 4C). In contrast, the pom 1 cdc25 double mutant, which grows only at one end (see above), could grow either at the old end (Fig. 4C) or the new end (not shown), in approximately equal frequency (Fig. 4D). Thus, cells lacking Pomlp appear to pick one end at random for growth after cell division and then, because of the defect in switching to bi pol ar growth, grow exclusively at this end until the next cell division.

Although most pom1 mutant cells picked one or the other end for growth after division, about $5 \%$ of cells mislocalized their growth axis altogether and formed angled or T-shaped cells (Figs. 1A and 5A,B). This phenotype was more dramatic in a poml cdcll double mutant. At restrictive temperature, the cdcll mutation causes a defect in cytokinesis, but the nuclear and growth cycles continue (Nurse et al. 1976; Mitchison and N urse 1985). cdc1l mutant cells grow at both ends after each mitosis, as reflected by the actin cytoskel eton, which forms rings during mitosis and cycles back to the cell ends during interphase (M arks et al. 1986). Presumably, after each mitosis, cdcll mutant cells must decide where to reinitiate growth. In the absence of Pom $1 p$, these decisions are often aberrant, leading to the formation of cells that are branched and often wildly so (Fig. 
A
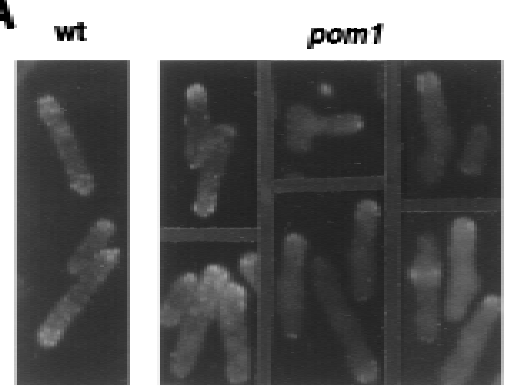

B
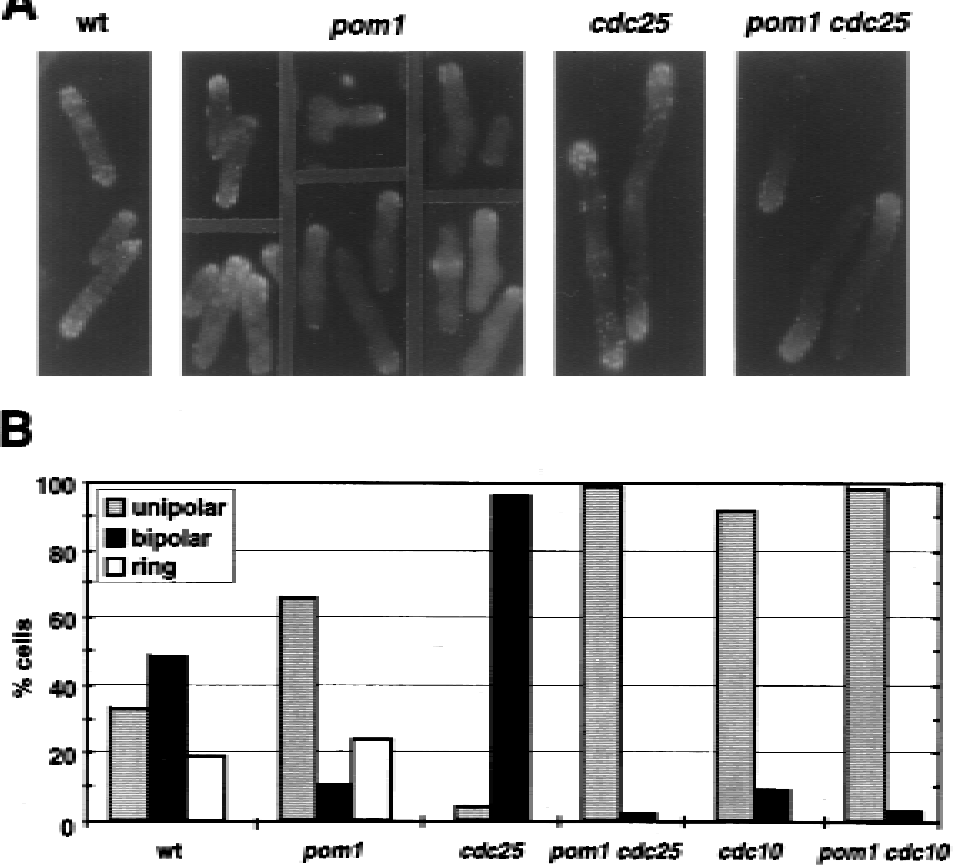

C cde10 pom1 cdeto celc25 pom1 cdc25
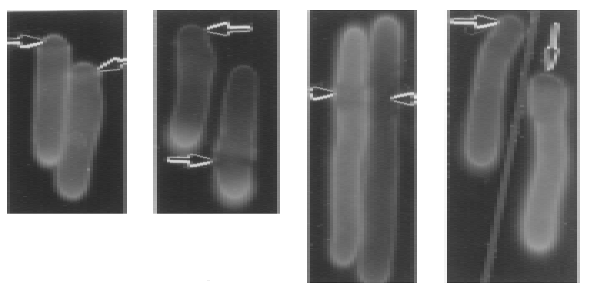

D

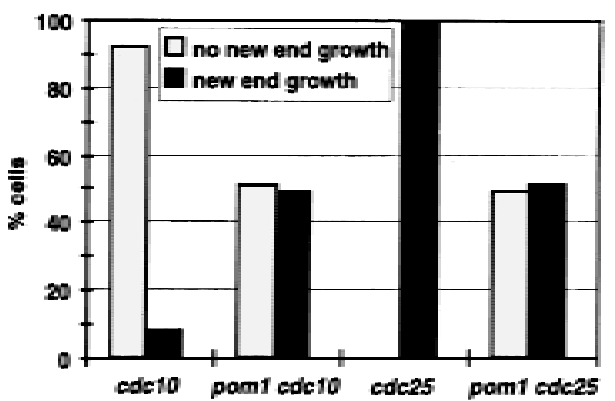

Figure 4. A bnormal polarization of growth in poml- $\Delta 1$ strains. (A) Strains 972 (wild type) and JB110 (pom1- $\Delta 1$ ) were grown at $36^{\circ} \mathrm{C}$ to $5 \times 10^{6} \mathrm{cells} / \mathrm{ml}$, then stained with rhodamine-phalloidin to visualize F-actin organization. Strains JB20 (cdc25-22) and JB120 (pom1- $\Delta 1 \mathrm{cdc} 25-22$ ) were grown to the same titer at $25^{\circ} \mathrm{C}$, then shifted to $36^{\circ} \mathrm{C}$ for $3 \mathrm{hr}$ before staining. (B) Cells from the populations shown in A were scored for unipolar or bipolar actin localization, as were cells of strains SP622 (cdc10-V50) and JB121 (pom1- $\Delta 1$ cdc10-V50) (grown as described for the cdc25-22 strains in A). For strains 972 and JB110, the percentages of cells with an actin ring were al so scored. In the other strains, these percentages were $\measuredangle \%$. At least 250 cells of each strain were eval uated. (C) Strains SP622, JB121, JB20, and JB120 were grown at $25^{\circ} \mathrm{C}$ to $5 \times 10^{6} \mathrm{cells} / \mathrm{ml}$, shifted to $36^{\circ} \mathrm{C}$ for $4 \mathrm{hr}$, and stained with Calcofluor. (D) Cells ( $\geqslant 250$ ) from each population shown in $\mathrm{C}$ were scored for the presence or absence of new-end growth.

$5 A, B)$. Staining for actin showed only one or two apparent growth zones per cell (data not shown), suggesting that the branching is caused by mislocalization of polarity in successive cell cycles and not by simultaneous activation of multiple growing ends. This interpretation is supported by the increase over time in the percentage of branched cells in the poml cdcll mutant (Fig. 5B); no such increase in cell branching over time was observed in pom 1 cdc10 or pom 1 cdc25 double mutants (Fig. $4 A, C$, and data not shown), in which repeated mitotic cycles did not occur.

\section{Microtubule organization in pom1 mutant cells}

Mutations or drugs that compromise microtubule function al so cause bending and branching of S. pombe cells (see introductory section). Therefore, we examined the microtubule cytoskel eton in pom1- $\Delta 1$ cells. The mutant cells displayed apparently normal arrays of interphase cytoplasmic microtubules (Fig. 5C, cells labeled 1) and normal mitotic spindles (Fig. 5C, cell 2). However, the mutant cells differed from wild-type cells in the placement of the post-anaphase microtubule-organizing centers, which nucleate the new cytopl asmic microtubules. In wild-type cells, these structures appear in the center of the cell (Fig. 5C, arrowhead; Hagan and Hyams 1988), but in pom 1 mutants they are frequently displaced from the center (Fig. 5C, arrows). The displaced microtubuleorganizing centers coincide with the misl ocal ized septa as visualized by differential-interference contrast (DIC) microscopy (data not shown).

\section{Genetic interactions of pom1}

To gain additional insights into the function of Pomlp, we investigated the possible genetic interactions (synthetic lethality, suppression, or epistasis) between pom1$\Delta 1$ and other mutations affecting cytoskeletal function and/ or cytokinesis (by use of strains indicated in Table 1, below). Interestingly, we observed synthetic lethal interactions between pom $1-\Delta 1$ and mutations affecting both the actin and microtubule cytoskeletons. In particular, pom1- $\Delta 1$ and the cold-sensitive act1-48 mutation (McCollum et al. 1996) were synthetical ly lethal at all temperatures tested $\left(18^{\circ} \mathrm{C}\right.$ to $\left.36^{\circ} \mathrm{C}\right)$. In addition, poml- $\Delta 1$ cdc3-6 (profilin; Balasubramanian et al. 1994) and pom1$\Delta 1$ cdc8-110 (tropomyosin; Balasubramanian et al. 1992) double mutants grew sl owly at $23^{\circ} \mathrm{C}$ and fai led to grow at $30^{\circ} \mathrm{C}$, temperatures at which the cdc3-6 and cdc8-110 single mutants grew well. Similarly, a pom1- $\Delta 1$ nda3KM311 ( $\beta$-tubulin; Hiraoka et al. 1984) double mutant failed to grow at $28^{\circ} \mathrm{C}$, a temperature at which the coldsensitive nda3-KM 311 single mutant grew well. In addition, a pom1- $\Delta 1$ ban5-3 ( $\alpha 2$-tubulin; Adachi et al. 1986; 


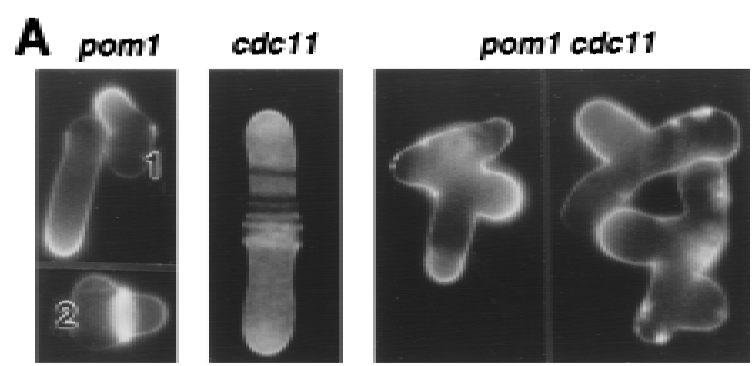

B

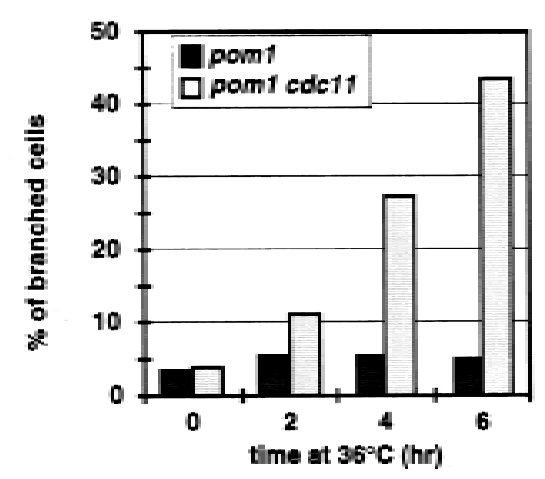

C
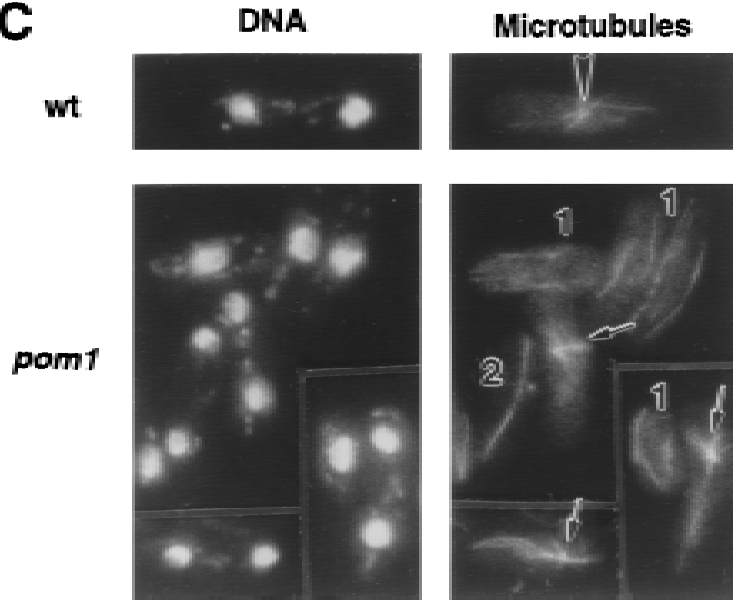

Figure 5. Mislocalization of growth poles and of microtubuleorganizing centers in pom1- $\Delta 1$ strains. (A) Cells of strains JB110 (pom1- $\Delta 1$ ), JB22 (cdc11-136), and JB122 (pom1- $\Delta 1$ cdc11-136) were grown at $25^{\circ} \mathrm{C}$ to $5 \times 10^{6} \mathrm{cells} / \mathrm{ml}$, shifted to $36^{\circ} \mathrm{C}$ for 4.5 $\mathrm{hr}$, and stained with Calcofluor. (B) 600 cells from each population shown in A were scored for the extent of cell branching as a function of time after the shift to $36^{\circ} \mathrm{C}$. The "branched" cell population in the pom $1-\Delta 1$ single mutant consisted mainly $(\sim 90 \%)$ of angled cells (see A, cell 1); the rest were T-shaped cells, the majority of which $(-90 \%)$ had a division scar at each end (see A, cell 2). The cdc11-136 single mutant showed $<1 \%$ cell branching at all times. (C) Cells of strains 972 and JB110 were grown at $30^{\circ} \mathrm{C}$ to $1 \times 10^{7} \mathrm{cell} / \mathrm{s} / \mathrm{ml}$, then fixed and stained with anti-tubulin antibodies and with bisBenzimide to visualize DNA. Some cells are numbered for reference in the text. (Arrowhead and arrows) Post-anaphase microtubule-organizing centers.

Yaffe et al. 1996) double mutant grew very slowly at $30^{\circ} \mathrm{C}$ and $36^{\circ} \mathrm{C}$, temperatures at which the ban5-3 single mutant grew well. pom1- $\Delta 1$ also showed a temperaturesensitive synthetic lethality with the cytokinesis mutations cdc14-118 (N urse et al. 1976; Fankhauser and Simanis 1993) and dmf1-6 (an allele of mid1; Sohrmann et al. 1996). A pom1- $\Delta 1$ tea $1 \Delta$ double mutant was viable at temperatures from $23^{\circ} \mathrm{C}$ to $36^{\circ} \mathrm{C}$ but showed an additive phenotype of strong cell branching (like the teal $\Delta$ single mutant; M ata and N urse 1997) and misplaced septa (like the pom1- $\Delta 1$ single mutant; see above). No obvious ge netic interactions were seen between pom1- $\Delta 1$ and arp3cl (actin-related protein; McCollum et al. 1996).

\section{Localization of Pom1p}

We used three methods to investigate the intracellular localization of Pomlp. First, we generated polyclonal anti bodies specific for Pomlp (see M aterials and M ethods). In addition, we tagged the $3^{\prime}$ end of poml (under its own promoter and in its normal genomic location) with sequences encoding either a triple hemaggl utinin epitope (3HA) or green fluorescent protein (GFP) (see Materials and $M$ ethods). The growth rates and cell morphologies of strains containing the tagged genes were indistinguishable from those of wild-type strains (data not shown), indicating that the tagged genes are functional. Immunofluorescence staining of wild-type cells with the Pomlp-specific antibodies, immunofluorescence staining of pom1-3HA cells with HA-specific antibodies, and observations on pom1-GFP cells all revealed the same patterns of Pomlp localization, as described bel ow. The fail ure of pom $1-\Delta 1$ cells to stain with the Pom $1 p$-specific antibodies (Fig. 6B) further confirmed the specificity of the staining. Because the tagged strains yielded stronger and more reproducible Pomlp local ization signals than did the Pomlp-specific antibodies, we used these strains for most of the studies described below.

Pomlp was observed at both cell ends in most cells (Fig. 6A,C,F), although one end usually had a stronger signal than the other. In some cells, Pomlp could also be observed in association with filaments (possibly microtubules; see below) running al ong the cell (Fig. 6C, arrows; Fig. 6F, white arrows). In addition, Pomlp was observed at the center of cells undergoing division (Fig. $6 \mathrm{D}, \mathrm{F}$, arrowheads). This signal was very faint in cells early in nuclear division (Fig. 6D,E, upper cell; Fig. 6F, cell $1,0 \mathrm{~min}$ ) but became much stronger as nuclear division and septation were completed (Fig. 6D,E, lower cell; Fig. 6F, cell 1, 10-45 min). The central Pom1p signal al ways spanned the full cell diameter (i.e., it did not appear to contract) until after cell division, when it marked the new ends of both daughter cells (Fig. 6F, cell 1, 45 and $75 \mathrm{~min}$ ).

The cell cycle dynamics of Pom1p localization were revealed most clearly by time-lapse studies of living pom1-GFP cells. In addition to the progressive changes in Pomlp signal at the cell center (see above), it was apparent that the new ends of cells had a high concentration of Pomlp at the time of birth and through much, if not all, of interphase (Fig. 6F, cell 1 daughters, 75-160 min; cells 2 and 3, 0-110 min). ( $N$ ote that cells 4 and 5 

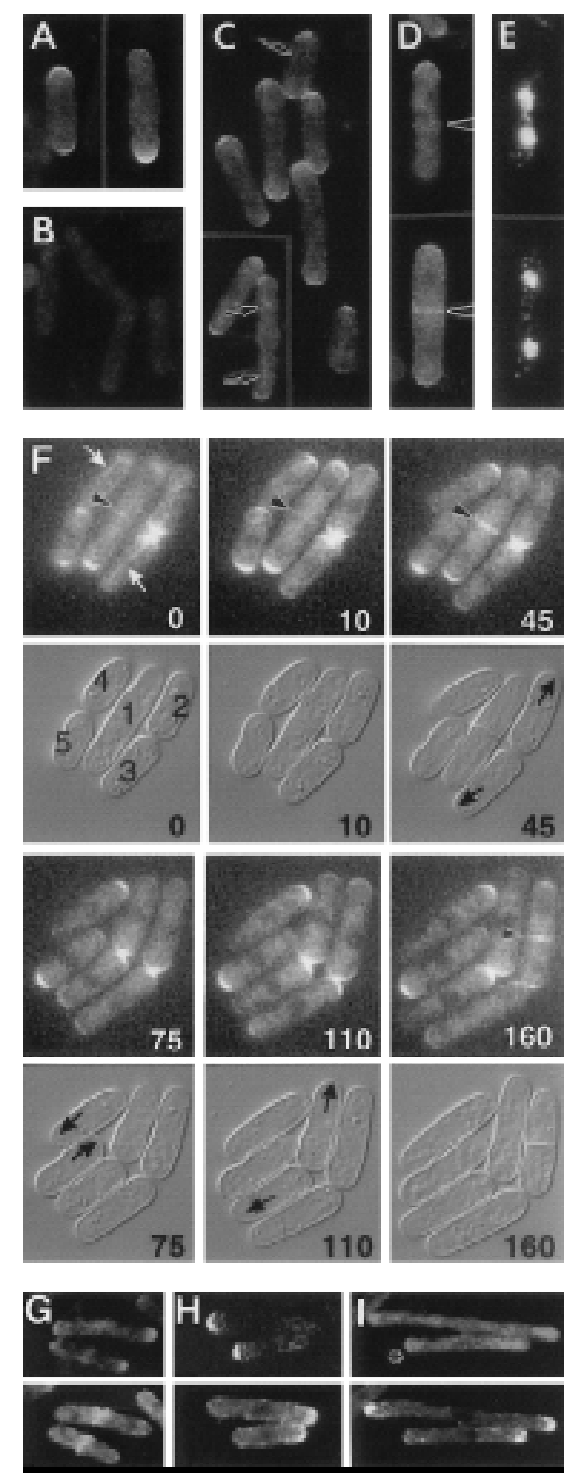

Figure 6. Localization of Pom1p. (A-E) Immunolocalization. All strains were grown at $30^{\circ} \mathrm{C}$. (A,B) Wild-type strain 972 (A) and pom1- $\Delta 1$ strain JB110 (B) were stained with antibodies to Pomlp. (C-E) The pom1-3HA strain JB1ll was stained with HA-specific antibodies (C) or double-stained with HA-specific antibodies (D) and bisBenzimide to visualize the DNA (E). Arrows and arrowheads indicate structures discussed in the text. (F) Time-lapse study of Pom1p-GFP localization through the cell-cycle. Strain JB115 was grown at room temperature in EM M medium and observed by fluorescence and DIC microscopy (see $M$ aterials and $M$ ethods). The times in minutes since the beginning of observation are indicated. Individual cells are numbered for reference in the text. (White arrows) Filamentous structures; (arrowheads) central Pomlp; (black arrows) growing ends. (G-I) Comparison of Pomlp and actin localization in wild-type and mutant strains. Cells expressing Pomlp-3HA were doublestained with antibodies to HA (top) and actin (bottom). (G) Strain JB111 (wild-type except for pom1-3HA) was grown at $30^{\circ} \mathrm{C}$ to exponential phase before staining. $(\mathrm{H}, \mathrm{I})$ cdc10-V50 strain JB113 $(\mathrm{H})$ and cdc25-22 strain JB114 (I) were grown at $25^{\circ} \mathrm{C}$ to $5 \times 10^{6} \mathrm{cells} / \mathrm{ml}$, then shifted to $36^{\circ} \mathrm{C}$ for $3 \mathrm{hr}$ before staining. were apparently nonsister cells that had happened to settle into the medium with their ol d ends adjacent.) The concentration of Pomlp seemed to be high and approximately equivalent at the two cell ends during the early stages of septum formation (Fig. 6F, cell 1, 10 min; cell 2, 110-160 $\mathrm{min}$ ) and then decreased while the concentration at the cell center increased as cell division proceeded (Fig. 6F, cell 1, 10-75 min).

\section{Actin independence of Pom1p localization}

Although Pomlp and actin both localize to the cell ends and to the cell center, their patterns of Iocalization through the cell cycle differ, as shown by comparison of the Pom 1p local ization descri bed above to the previously described distribution of actin (see introductory section) and by double-staining experiments (Fig. 6G-I). In wildtype cells, when actin relocalized from the cell ends to the cell center in preparation for division, Pom1p was still found predominantly at the cell ends, although a small amount of Pom1p colocalized with the central actin (Fig. 6G). In interphase cells, there was typically a negative correlation between the amount of Pomlp and the amount of actin at a particular end, which reflects, at least in part, the high concentration of Pomlp at the new end (Fig. 6F) and the high concentration of actin at the old end (Marks and Hyams 1985) in recently divided cells. This negative correlation was also apparent in cdc10 and cdc25 mutant backgrounds. In cdc10-V50 cells, where actin was concentrated only at the old end, Pom 1p was found al most excl usi vely at the new end (Fig. $6 \mathrm{H}$ ). In cdc25-22 cells, where actin was typically concentrated at both ends (Fig. 4A,B; Fig. 6I), only small amounts of Pom1p were typically seen at either end (Fig. $61)$. In some cdc25-22 cells, particular ends had lower concentrations of actin; such ends typically also had more distinct concentrations of Pomlp (Fig. 6l, asterisk).

These results suggested that Pomlp localization does not depend on actin. To test this hypothesis, we treated cells with the inhibitor latrunculin-A (LAT-A), which quickly and completely disrupts the S. cerevisiae actin cytoskeleton (Ayscough et al. 1997). S. pombe cells treated for $3 \mathrm{hr}$ with LAT-A had no remaining visible actin structures (Fig. 7A, right), but Pom1p was still localized to the cell ends (Fig. 7A, left), indicating that Pom1p localization to the cell ends is indeed independent of actin. In contrast, Pom1p was not observed at the cell centers in LAT-A-treated cells, suggesting that actin is required (directly or indirectly) for localization of Pomlp to the division site. In some LAT-A-treated cells, small amounts of Pomlp were al so observed in association with filament-like structures (Fig. 7A, arrows), as noted also in untreated cells (Fig. 6C,F). Thus, these structures do not appear to be actin filaments.

\section{Microtubule dependence of Pom1p localization}

To ask whether Pomlp localization depends on the microtubule cytoskel eton, we depolymerized microtubules using thiabendazole (TBZ; U mesono et al. 1983). Treat- 
Pomlp and positional information in S. pombe

A

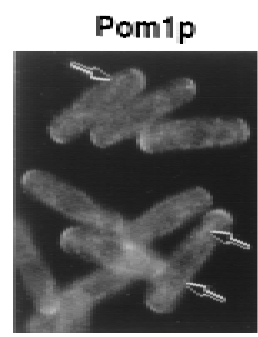

C

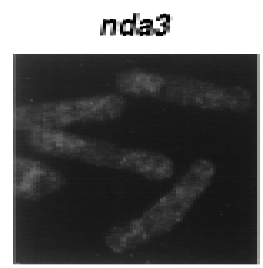

D

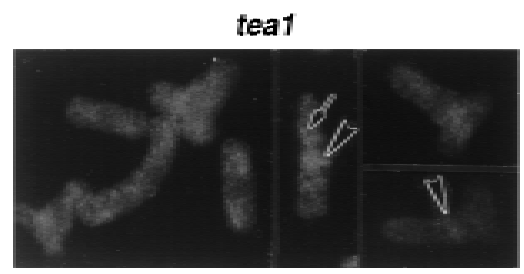

E
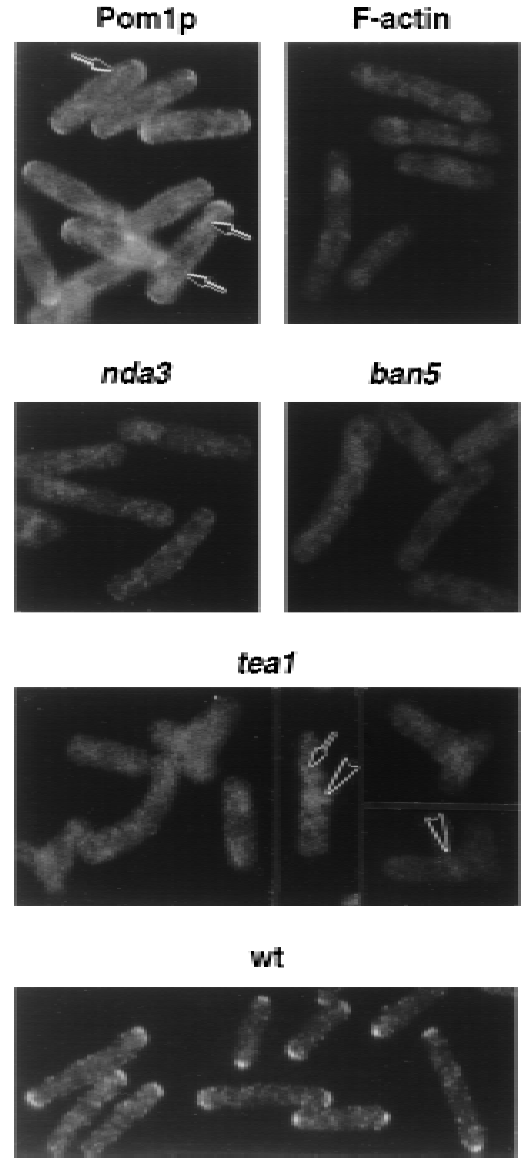

ban5

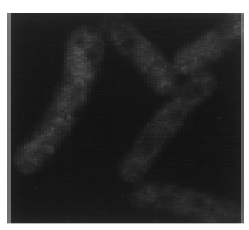

teat
B

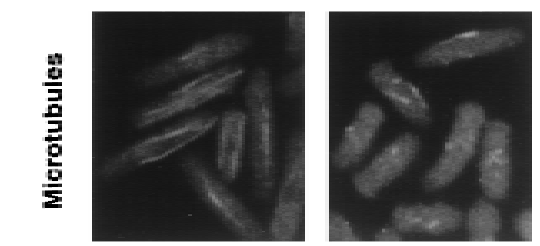

pom1

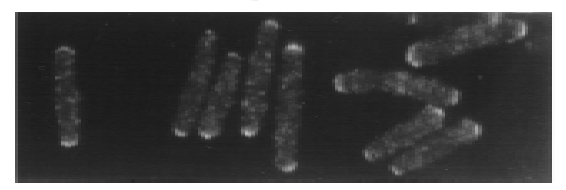

Figure 7. Effects of cytoskeletal inhibitors and mutations on Pom1p local ization. All strains expressed Pomlp-3HA and were stained with antibodies to HA. Arrows and arrowheads indicate structures discussed in the text. (A) Strain JB111 (wild type) was grown at $30^{\circ} \mathrm{C}$ to $2 \times 10^{6}$ cells/ml, and LAT-A was added to $100 \mu \mathrm{m}$. After $3 \mathrm{hr}$, cells were stained separately for Pomlp and for F-actin (using rhodaminephalloidin). (B) Strain JB111 was grown at $30^{\circ} \mathrm{C}$ to $5 \times 10^{6}$ cells $/ \mathrm{ml}$ and TBZ was added to $100 \mu \mathrm{g} / \mathrm{ml}$ (right panels). A control culture (left panels) received no TBZ. After $1 \mathrm{hr}$, aliquots of cells from each culture were double-stained for Pom1p (top panels) and DNA (middle panels) or stained separately for microtubules (bottom panels). (C) Strain JB130 (nda3$\mathrm{KM} 311$; left panel) was grown at $32^{\circ} \mathrm{C}$ to $5 \times 10^{6} \mathrm{cells} / \mathrm{ml}$ and shifted to $20^{\circ} \mathrm{C}$ for 1.5 hr before staining for Pom1p. Strain JB132 (ban5-3; right panel) was grown at $25^{\circ} \mathrm{C}$ to $5 \times 10^{6} \mathrm{cells} / \mathrm{ml}$ and shifted to $36^{\circ} \mathrm{C}$ for 3 hr before staining for Pomlp. (D) Strain JB131 (tea1-1) was grown at $25^{\circ} \mathrm{C}$ to $5 \times 10^{6} \mathrm{cells} / \mathrm{ml}$, shifted to $36^{\circ} \mathrm{C}$ for $3.5 \mathrm{hr}$, and stained for Pomlp. (E) Strains 972 (wild type) and JB110 (pom1- $\Delta 1$ ) growing exponentially at $30^{\circ} \mathrm{C}$ were fixed and stained with antibodies to Tealp. ment of cells with TBZ for $\geqslant 60$ min caused a drastic shortening of mi crotubul es and essentially complete loss of Pomlp from the cell ends (Fig. 7B), and a significant decrease in the Pomlp staining of cell ends could be detected within $10 \mathrm{~min}$ of TBZ addition (data not shown). Thus, the pol ar local ization of Pomlp appears to depend directly or indirectly on microtubules. In contrast, some TBZ-treated cells still showed Pomlp staining at the cell centers (Fig. 7B, right, arrowhead), indicating either that this aspect of Pomlp localization is microtubule independent or that the short residual microtubules near the cell nucleus are sufficient for it. In some TBZ-treated cells, Pomlp staining was observed along short filaments (Fig. 7B, right, arrows) that were probably residual spindle microtubules, as judged from their colocalization with the nuclear DNA. This observation suggests that Pom1p has some affinity for microtubules and that the filaments seen in untreated cells (Figs. 6, C and F, and 7, A and B, left, arrows) may represent microtubules. Indeed, the positions of some of these Pomlp-stained filaments suggested that they might be spindles (Fig. 7B, left, arrows), raising the possibility that a fraction of Pomlp localizes to the spindle during mitosis.

To confirm that the loss of Pomlp localization from the cell ends in TBZ-treated cells was caused by disas- sembly of microtubules and not by some other effect of the drug, we also examined conditional nda3 and atb2 mutants. These tubul in mutations caused a more nearly complete loss of microtubules than did TBZ treatment (data not shown). As expected, both mutants failed to localize Pom1p to the cell ends (Fig. 7C); in addition, the mutant cells did not show detectable Pomlp at the cell center (see Discussion).

\section{Relationship between Pom1p and Tealp localization}

Like pom1 mutants, teal mutants form branched cells (Snell and N urse 1994; Verde et al. 1995), and Tealp al so localizes to the cell ends in a microtubule-dependent manner (M ata and N urse 1997). Thus, we examined the relationship between Pom $1 p$ and Tealp local ization. In a teal mutant, Pom 1p was not observed at the cell ends at either $25^{\circ} \mathrm{C}$ (data not shown) or $36^{\circ} \mathrm{C}$ (Fig. 7D), al though some cells did show weak Pomlp signal s al ong filaments (Fig. 7D, arrow) and/or at the cell center (Fig. 7D, arrowheads). In contrast, Tealp localization appeared normal in a pom1- $\Delta 1$ strain (Fig. 7E). Thus, Tealp localization does not require Pomlp, but at least some aspects of Pom1p localization depend directly or indirectly on Tealp. 


\section{Discussion}

This report describes a novel S. pombe gene, pom1, whose product is required for the proper positioning of growth zones and division septa but not for polarized growth or division per se. Although the available data do not yet allow a comprehensive model of Pomlp function, there are intriguing clues to its role in each of the processes in which it is implicated.

Role of Pomlp in distinguishing the old from the new cell end

An important problem in S. pombe morphogenesis is how a newborn cell distinguishes its old end (which will grow immediately) from its new end (which will grow only after a delay). Pomlp is the first protein shown to play a critical role in this process: In pom 1 mutants, newborn cells initiate growth from either end with equal frequency. Strikingly, in newborn wild-type cells, Pomlp is highly concentrated at the new end and virtually absent from the old end. This suggests that the high concentration of Pomlp may mark the new end as such and provide a negative signal for assembly of the growth machinery at that end. However, a negative signal from Pomlp cannot be the only mechanism determining the selection of a growth pole, because wild-type cells faithfully begin growth from the old end and not from the sides of the cell, and even pom 1 mutant cells usually begin growth from one end or the other.

\section{Role of Pomlp in defining the ends of the cell}

About $5 \%$ of pom 1 mutant cells show a defect in orientation of the growth axis relative to the ends and sides of the cell, leading to the formation of angled and T-shaped cells. Similar aberrations are more frequent in the teal and tea2 mutants Nerde et al. 1995; Mata and Nurse 1997), suggesting that the cytoplasmic microtubule/ Tealp (and perhaps Tea2p) system (Mata and Nurse 1997) plays the primary role in defining the ends of the cell and that Pom1p plays a secondary role, perhaps as one of several factors communicating positional information from the cytoplasmic microtubule/Tea protein system to the actin cytoskel eton (see also below). In this regard, the extensively branched cells produced by the cdcl1 pom1 double mutant are of interest. As a cdcll mutant reorganizes growth poles after each mitosis and failed cytokinesis (M itchison and N urse 1985; Marks et al. 1986), the extensive branching of the cdcll pom1 double mutant may reflect primarily the inappropriate resumption of growth from "new ends" (actually the centers of the cells because of the failure of cytokinesis) after mitosis in the absence of Pomlp and only secondarily the difficulties of Pom1p-deficient cells in orienting the growth axis relative to the ends and sides of the cell. Consistent with this interpretation, cdc10 pom1 and cdc 25 pom 1 double mutants, which do not undergo repeated cycles of mitosis and failed cytokinesis, do not branch upon extended arrest, although the cells are less straight than those of cdc10 and cdc25 single mutants. Taken together, the results suggest that a major role of Pom 1p is in proper polarity re-establishment after mitosis.

\section{Role of Pom1p in NETO and the function of bipolar} growth

During interphase, Pom $1 p$ is required for the initiation of a second growth pole at the new end (NETO): pom 1 mutant cells continue to grow at the one randomly selected end until division. It is possible that NETO is normally triggered by a loss of the negative signal hypothesized to prevent growth at the new end immediately after division; although the concentration of Pomlp at the new end seems to remain high until well after NETO, the protein might be inactivated at the appropriate stage in the cell cycle. However, in this case, one would expect a pom1 mutant to initiate bipolar growth immediately after cell division. Thus, it seems more likely that Pom 1p plays a positive role in the establishment of bi polar growth; for example, a change in Pom1p substrate specificity at the appropriate cell cycle stage might simultaneously eliminate the negative signal and produce a positive signal for recruitment of the growth machinery to the new end. Further studies will be needed to discriminate among these and other possible models.

Whatever the actual role of Pomlp in NETO and the establishment of bipolar growth, the viability of the pom1- $\Delta 1$ mutant demonstrates that NETO is not essential for viability or cell-cycle progression. This conclusion is supported by observations on other mutants (tea1, orb2, and ban2) with NETO defects (Verde et al. 1995). However, the switch to bipolar growth may provide for more efficient cell el ongation. On average, pom 1 mutant cells are about $10 \%$ shorter than wild-type cells during septation. M oreover, pom1 cdc 25 double-mutant cells are clearly shorter on average than cdc25 singlemutant cells (Fig. 4A,C). In addition, bipolar growth may contribute to the cell's ability to distinguish its ends from its sides: It was striking that most T-shaped pom 1 mutant cells had a division scar at each of the original cell ends (such as would result from old end growth, without NETO, followed by division), suggesting that ends that had not grown were not recognized efficiently as appropriate sites for polarized growth.

Role of Pomlp in the positioning and orientation of division planes

The phenotypes of pom 1 mutants and of the other mutants (mid1 and pos1, pos2, and pos3) with misplaced division sites suggest some general conclusions about the mechanisms governing the positioning and orientation of division planes in S. pombe. First, all of the mutants produce septa that are misoriented (i.e., not orthogonal to the long axis of the cell) as well as misplaced (Chang et al. 1996; Edamatsu and Toyoshima 1996; Sohrmann et al. 1996; this study); this suggests that the 
mechanisms for positioning and orienting division planes are rel ated. Second, at least in the midl and pom 1 mutants, the post-anaphase microtubule-organizing centers are also misplaced (Chang et al. 1996; this study), suggesting that their placement is governed by the same signal(s) that govern the placement of division sites. Finally, in both midl and pom 1 mutants (this is less clear for the pos mutants; see Edamatsu and T oyoshima 1996), septa that would form anucleate cells do not seem to be cleaved (Chang et al. 1996; this study), raising the possibility of a checkpoint that monitors whether there is a nucleus on either si de of the septation site (Chang et al. 1996).

Despite such insights, the mechanisms controlling septum placement in S. pombe remain poorly understood. Among several possible models, the most attractive at present is that the position of the nucleus determines the position of the division site (Chang and N urse 1996). In this regard, it is of interest that Pomlp was not detected in or associated with the nucleus (except for the possible association of some Pom 1p with spindle microtubules). However, Pomlp might be involved in receiving and/or transmitting a signal (perhaps carried by Midlp; see introductory section and Sohrmann et al. 1996) that emanates from the nucleus. Whether or not the signal for positioning the division site originates in the nucleus, Pom 1p might be involved either in di recting components of the cytokinesis machinery to the cell center or in anchoring them there. Consistent with these possibilities, a faint Pom $1 p$ signal was detected at the center of cells at the beginning of nuclear division, which is approximately the time at which the medial actin ring also appears. However, this ring constricts during septation (J ochová et al. 1991; M cCollum et al. 1995; Kitayama et al. 1997), whereas the centrally located Pomlp signal spans the full cell diameter both during and after septum formation. Thus, Pomlp is unlikely to be a structural component of the medial actin ring.

It is also striking that in all of the known mutants with misplaced septa, the nuclei themselves are positioned normally at the cell center during interphase and appear to divide normally. It is possible that in all of these mutants, the hypothetical signal either is not sent by the nucleus or cannot be received by the cell cortex, and that in the absence of a signal, the division machinery is free to assemble at an abnormal position. However, these observations also might indicate that the positional information for division does not in fact come from the nucleus.

Another challenge for the nuclear-signal model is posed by the observation that pom 1 mutants preferentially place their septa closer to the nongrowing end of the cell. It is not yet cl ear whether such a bias al so exists in the other mutants with defects in septum placement. This bias could be reconciled with the model by supposing that the cortical site is marked by the nucleus during interphase and then gets displaced from the cell center by the continuing unipolar growth of the pom 1 mutant cells. In this case, Pom lp might actually play no direct role in selection of the division site, and the septum- localization defect would be merely an indirect effect of the failure of NETO. (The movement of Pomlp to the cell center might in this case be only a step toward the marking of the new end after division.) However, early marking of the cortical site is difficult to reconcile with the behavior of other mutants such as wee1, tea1, orb2, and ban2, which divide symmetrically despite growing mainly from one end (Mitchison and N urse 1985; Verde et al . 1995; Chang and N urse 1996). Moreover, if Pom1p plays no direct role in selection of the division site, it is hard to understand why septum orientation as well as septum placement is perturbed in pom 1 mutants and why pom 1 mutations show genetic interactions with mutations affecting cytokinesis.

Interactions of Pomlp with the actin and microtubule cytoskeletons

In S. pombe, actin is required for polarized growth and the cytoplasmic microtubules are involved in the positioning of such growth (see introductory section). Thus, a possible role for Pomlp is in the signal chain that communicates positional information from the microtubules to the actin cytoskeleton. Consistent with this hypothesis, Pom $1 p$ requires microtubules, but not actin, for local ization to the cell ends, and some Pom 1p may local ize along microtubules. Moreover, pom1 mutations show synthetic-lethal interactions both with tubulin mutations and with actin cytoskeleton mutations. Pom 1p appears to be a protein kinase, and it might function by phosphorylating one or more components of the actin cytoskeleton. However, this general view of Pomlp function faces the difficulty that although Pomlp and actin both localize to the same regions of the cell, they do not do so synchronously. Indeed, at the cell ends, the concentration of actin is typically high when that of Pomlp is low, and vice versa. There are at least three possible explanations for these observations. First, the level of Pom1p protein kinase activity may not always simply reflect the abundance of the protein. Second, as noted above, the specificity of Pomlp may be altered in response to cell cycle signals, so that it could provide both positive and negative signals to the actin cytoskeleton at different times. Finally, as the localization of Pomlp is dynamic, it could be marking sites at one time that are used only later; for example, the Pomlp that accumulates transiently at the old end prior to septation may mark this site for actin assembly in the next cell cycle.

Examination of events at the cell center also does not reveal a simple story. A faint Pomlp signal is observed at about the same time that the actin ring forms, but it is not clear that the Pom1p is present in time to direct actin to that site. Subsequently, actin patches become highly concentrated at the cell center before the major increase in Pomlp concentration at that site. Moreover, in pom 1 mutants, actin rings form and actin patches become concentrated at the septation sites, even when these are misplaced. Finally, it is not clear whether microtubules, actin, or both are involved in localizing 
Pomlp to the cell center. In addition to the cytoplasmic and spindle pole body-associated microtubules present earl ier in the cell cycle (Hagan and Hyams 1988; Ding et al. 1997), a microtubule ring colocalizes with the medial actin ring during nuclear division (Pichová et al. 1995). We did not detect Pom1p at the cell center in tubulin mutant cells, but some TBZ-treated cells still showed central Pom1p localization. This localization might have been attributable to residual microtubules in the TBZtreated cells; alternatively, the failure of central Pom1p localization in the mutants might be an indirect effect of cell cycle blockage resulting from the loss of microtubules. We al so did not detect central Pomlp staining in LAT-A-treated cells; it is not yet clear whether this reflects a direct or indirect effect of the loss of actin function.

\section{Functional relationship of Pomlp and Tealp}

Like Pom1p, Tealp requires microtubules for Iocalization to the cell ends ( $M$ ata and N urse 1997). However, the detailed patterns of Pomlp and Tealp localization differ. Moreover, al though Tealp requires continuous microtubule function to maintain its local ization at the cell ends (M ata and N urse 1997), Pom1p del ocal izes and relocalizes only slowly in response to microtubule disruption and recovery, respectively (see Results; J. Bähler, unpubl.), and it remains concentrated at the cell ends when the cytoplasmic microtubules disassemble at the time of spindle formation. In addition, Tealp, unlike Pom1p, local izes to the tips of mi crotubules and directly affects mi crotubule organization (M ata and N urse 1997). Thus, the mechanisms for delivery and/or retention of Pomlp and Tealp to the cell ends may differ.

Interestingly, Pom $1 p$ requires Tealp for local ization to the cell ends, whereas Tealp localization is independent of Pomlp. This suggests that Pomlp acts downstream of Tealp at the cell ends. In this case, teal mutants should show the same abnormalities as do pom1 mutants. Indeed, there are striking similarities in the mutant phenotypes, such as the formation of $\mathrm{T}$-shaped cells and the N ETO defects (Verde et al . 1995; M ata and N urse 1997). Moreover, some teal cells seem to initiate growth at the new end after cytokinesis (J. M ata and P. N urse, pers. comm.). However, Tealp does not appear to function exclusively through Pom $1 p$, as teal mutants have the additional phenotypes of abnormal microtubule organization and more prevalent cell branching ( $M$ ata and N urse 1997). Conversely, Pomlp appears to have some functions that are independent of Tealp, as Pomlp localizes to the cell center (although, interestingly, not to high levels) in the absence of Tealp, and teal mutants are not defective in septum placement. M oreover, a teal poml double mutant shows an additive phenotype, consistent with the hypothesis that Tealp and Pom 1p act in part in a common pathway, but that each protein has additional independent function(s).

\section{Conclusions}

Pomlp is involved in providing positional information both for polarized growth and for cell division in S. pombe. Both processes involve assembly of actin and associated proteins at defined sites, and Pom1p may transmit positional information from the microtubule to the actin cytoskeleton. However, at present the exact role of Pomlp in directing the organization of the actin cytoskeleton is not clear; it may involve negative signals, positive signals, or both. It will be important to identify proteins that interact with Pomlp, either as regulators or as substrates, and to examine the role and cell cycle regulation of the putative protein kinase activity. As signaling pathways involving protein kinases may also be important in the organization of the actin and/or microtubule cytoskel etons in other eukaryotes, elucidation of the mechanisms of Pomlp function should be of general interest for an understanding of eukaryotic cellular morphogenesis.

\section{Materials and methods}

\section{Strains, growth conditions, and inhibitor methods}

The S. pombe strains used are listed in Table 1; all are isogenic to 972 (Leupold 1970). Standard growth media were used (M oreno et al. 1991); except where noted, cells for experiments were grown at $30^{\circ} \mathrm{C}$ in EMM minimal medium. Growth rates were determined both in $\mathrm{EM} M$ and in $\mathrm{YE}$ rich liquid medium at $23^{\circ} \mathrm{C}, 30^{\circ} \mathrm{C}$, and $36^{\circ} \mathrm{C}$; exponentially growing cultures $\left(<5 \times 10^{6}\right.$ cells $/ \mathrm{ml}$ ) were diluted twofold, and the times required for return to the original absorbances were measured. For experiments with microtubule and actin inhibitors, cells were grown to early exponential phase $\left(<3 \times 10^{6} \mathrm{cel} / \mathrm{s} / \mathrm{ml}\right)$. TBZ (Sigma; final concentration $20-100 \mu \mathrm{g} / \mathrm{ml}$ ) or LAT-A (M olecular Probes; final concentration $100 \mu \mathrm{m}$ ) was then added, and the culture was incubated further before examination.

\section{Genetic and molecular biology methods}

Standard genetic and recombinant DN A methods (M oreno et al. 1991; Sambrook et al. 1989) were used except where noted. Y east transformations were performed by use of a lithium acetate method (Keeney and Boeke 1994). DN A was prepared from bacteria and isolated from agarose gels by use of Qiagen kits and from yeast cells as described by Hoffman and Winston (1987). DNA was sequenced by the UNC-Chapel Hill Automated Sequencing Facility. Oligonucleotide primers were obtained from Integrated DNA Technologies.

\section{Mutant screen}

Strain 972 was grown in EM M medium to stationary phase and mutagenized with $300 \mu \mathrm{m}$ nitrosoguanidine (Sigma) for $60 \mathrm{~min}$ ( $10 \%$ survival) as described by M oreno et al. (1991). Individual colonies of mutagenized cells were picked into $20-\mu$ l al iquots of water in the wells of microtiter plates. Cells were then transferred with a multiprong device onto two YE plates and two plates of YE containing 6\% ethanol (Jimenez and Oballe 1994); one plate of each type was incubated at $25^{\circ} \mathrm{C}$ and one at $36^{\circ} \mathrm{C}$. All plates contained $2 \mu \mathrm{g} / \mathrm{ml}$ phloxin B, which accumulates in dead cells (Kohli et al. 1977). Growth of the clones was scored after three days. Cells were then transferred with the multiprong device from the $Y E$ +ethanol plates at $36^{\circ} \mathrm{C}$ to microtiter plates with $50 \mu \mathrm{l}$ of water in each well, and 10- $\mu \mathrm{l}$ aliquots of the clonal cell suspensions were then spotted with a multipipettor 
Table 1. S. pombe strains used in this study

\begin{tabular}{|c|c|c|}
\hline Strain & Genotype & Reference/Source \\
\hline 972 & wild-type $\mathrm{h}^{-}$ & Leupold (1970) \\
\hline JB12 & leu1-32 $\mathrm{h}^{+}$ & J. Kohli, \\
\hline JB16 & ade6-M210/ade6-M216 ura4-D18/ura4-D 18 h-/h+ & this study ${ }^{a}$ \\
\hline JB20 & $\operatorname{cdc} 25-22 \mathrm{~h}^{-}$ & Thuriaux et al. (1980) \\
\hline SP622 & cdc10-V50 ura4-D18 $\mathrm{h}^{-}$ & Reymond et al. (1992) \\
\hline JB22 & cdc11-136 leu1-32 $\mathrm{h}^{-}$ & N urse et al. (1976) \\
\hline JB23 & cdc14-118 leu1-32 h- & N urse et al. (1976) \\
\hline JB24 & $\operatorname{cdc} 3-6 \mathrm{~h}^{-}$ & N urse et al. (1976) \\
\hline JB26 & cdc8-110 $\mathrm{h}^{-}$ & N urse et al. (1976) \\
\hline JB30 & nda3-KM311 leu1-32 $\mathrm{h}^{-}$ & Umesono et al. (1983) \\
\hline JB31 & tea1-1 leu1-32 ura4-D18 $\mathrm{h}^{+}$ & Snell and Nurse (1994) \\
\hline JB32 & ban5-3b ade6-M210 leu1-32 h- & Verde et al. (1995) \\
\hline JB40 & dmf1-6 leu1-32 $\mathrm{h}^{-}$ & Sohrmann et al. (1996) \\
\hline JB50 & tea1s leu1-32 ura4-D18 $\mathrm{h}^{-}$ & Mata and N urse (1997) \\
\hline KGY 1010 & act1-48 leu1-32 lys1-131 ura4-D18 h- & McCollum et al. (1996) \\
\hline YDM 188 & arp3-c1 ade6-M210 leu1-32 ura4-D18 h- & McCollum et al. (1996) \\
\hline JB99 & poml-1 $\mathrm{h}^{+}$ & see text \\
\hline JB100 & pom1-1 leu1-32 $\mathrm{h}^{-}$ & see text \\
\hline JB101 & pom1-1 cdc14-118 leu1-32 h- & JB23 ×JB99 \\
\hline JB102 & pom1-1 dmf1-6 leu1-32 $\mathrm{h}^{-}$ & JB40 × JB99 \\
\hline JB109 & pom1- $\Delta 1$ ade6-M216 ura4-D18 $\mathrm{h}^{+}$ & see text \\
\hline JB110 & pom1- $\Delta 1$ ura4-D18 $\mathrm{h}^{-}$ & $972 \times J B 109$ \\
\hline JB111 & pom1-3HA h ${ }^{-}$ & see text \\
\hline $\mathrm{JB} 112$ & pom1-3HA h ${ }^{+}$ & see text \\
\hline JB113 & pom1-3HA cdc10-V50 $\mathrm{h}^{-}$ & $\mathrm{SP} 622 \times \mathrm{JB} 112$ \\
\hline JB114 & pom1-3HA cdc $25-22 \mathrm{~h}^{-}$ & $\mathrm{JB} 20 \times \mathrm{JB} 112$ \\
\hline JB115 & pom1-GFPS65T $\mathrm{h}^{-}$ & see text \\
\hline JB120 & pom1- $\Delta 1$ cdc25-22 ura4-D18 $\mathrm{h}^{-}$ & JB20 ×JB109 \\
\hline JB121 & pom1- $\Delta 1$ cdc10-V50 ura4-D $18 \mathrm{~h}^{-}$ & SP622 ×JB109 \\
\hline JB122 & pom1- $\Delta 1$ cdc11-136 ura4-D18 $\mathrm{h}^{-}$ & JB22 ×JB109 \\
\hline JB130 & pom1-3HA nda3-KM311 $\mathrm{h}^{-}$ & $\mathrm{JB} 30 \times \mathrm{JB} 112$ \\
\hline JB131 & pom1-3HA teal-1 $\mathrm{h}^{-}$ & JB31 ×JB111 \\
\hline JB132 & pom1-3HA ban5-3 $3^{b} \mathrm{~h}^{-}$ & $\mathrm{JB} 32 \times \mathrm{JB} 112$ \\
\hline
\end{tabular}

Derived by mating two haploid strains obtained from J. Kohli.

bban5-3 is an allele of atb2 (Adachi et al. 1986; Y affe et al. 1996), one of the two genes for $\alpha$-tubulin in S. pombe.

onto gelatin-coated slides, stained with Calcofluor, and examined by fluorescence microscopy (Zahner et al. 1996). Clones that showed aberrations in cell shape, cell division, and/or Calcofluor staining pattern were recovered for further analysis from the YE plates that had been kept at $25^{\circ} \mathrm{C}$. The original pom1-1 mutant was backcrossed four times to wild-type strains JB12 and 972, yielding strains JB99 and JB100, before detailed characterization.

\section{Cloning, deletion, and tagging of pom1}

To clone pom1, we exploited the observations that the pom1-1 dmf1- 6 and pom1-1 cdc14-118 double mutants are viable (although slow growing) at $23^{\circ} \mathrm{C}$ but inviable at $30^{\circ} \mathrm{C}$. Double mutants that also carried leu1-32 (strains JB101 and JB102) were grown at $23^{\circ} \mathrm{C}$ and transformed with a S. pombe genomic DN A library (a gift from P. Young, Queens University, Ontario, Canada) constructed in plasmid pWH5 (Wright et al. 1986). Leu ${ }^{+}$ transformants were grown for $12 \mathrm{hr}$ at $23^{\circ} \mathrm{C}$ and then shifted to $30^{\circ} \mathrm{C}$ for three days. Plasmid DNA was recovered from three transformants that showed plasmid-dependent rescue. These plasmids had identical or overlapping inserts as judged from restriction digests, and all three complemented both of the double mutants as well as the pom1-1 single mutant (strain
JB100) upon retransformation. The ORF responsible for complementation of pom1-1 was identified by gel purification of different restriction fragments of the original inserts and cotransformation of these fragments into strains JB101 and JB102 al ong with plasmid pREP3 (M aundrell 1993). (M any transformants selected for the pREP3 selectable marker also have the cotransformed fragment integrated in the genome.) In addition, CDN A clones containing partial poml sequences (codons 696-1087) were recovered from two different libraries (Fikes et al. 1990; Kelly et al. 1993) by colony hybridization.

pom 1 was deleted by use of a PCR-generated fragment (Bähler et al. 1998). The S. pombe ura $4^{+}$gene was amplified by use of plasmid KS-ura4 (which contains ura4 ${ }^{+}$as a 1.8-kb Hindlll fragment in the HindlII site of pBluescript $\mathrm{KS}^{-}$; a gift from S. Parisi, University of Bern, Switzerland) as template, a forward primer that contained 76 nucleotides from the 5 '-end of pom 1 (from position -55 to +21 relative to the start of the ORF) and the 24 nucleotides of the $\mathrm{M} 13$ forward primer, and a reverse primer that contained 76 nucleotides from the 3 '-end of pom 1 (the last five codons of the ORF and the 61 nucleotides immediately downstream) and the 24 nucleotides of the $M 13$ reverse primer. The PCR product was purified by phenol extraction and transformed into diploid strain JB16 under selection for $\mathrm{U} \mathrm{ra}^{+}$. Genomic DNAs from 16 transformants were checked by PCR for 
integration of $\mathrm{ura}^{+}{ }^{+}$at the pom 1 locus, using the forward primer (see above) together with a primer corresponding to nucleotides 78-105 downstream of the pom1 stop codon. Six transformants produced a PCR fragment of the expected size (1.9 kb). Tetrads were dissected from four of these transformants. M ost tetrads yielded four viable spores, and all of the four-spored tetrads showed a 2:2 segregation of U ra+:U ra ${ }^{-}$that correlated with the presence of the pom 1 phenotype and the PCR product diagnostic for correct integration. Strain JB109 is one of these segregants; its deletion allele was designated pom $1-\Delta 1$ and used in further analyses. The success of the deletion construction was also confirmed by Southern blotting (data not shown).

Pom lp was tagged at its carboxyl terminus with GFP carrying the S65T mutation (Heim et al. 1995) or with a 3HA epitope by direct chromosomal integration of PCR-generated fragments (Bähler et al. 1998). Sequences encoding each tag together with a G418-resistance marker were amplified with plasmids pFA6aGFP(S65T)-kanMX6 and pFA6a-3HA-kanMX6 as templates. The two primers had 80-bp tails corresponding to the regions just upstream and 200-280 bp downstream of the poml stop codon. The PCR fragments were then used to transform strain 972. Transformants were selected on YE plates containing 100 $\mu \mathrm{g} / \mathrm{ml} \mathrm{G} 418$ (Geneticin; Life Technologies), and both junctions were checked for correct integration by PCR using primers hybridizing to the kanamycin marker and primers hybridizing $2400 \mathrm{bp}$ upstream or $400 \mathrm{bp}$ downstream of the pom1 stop codon. For each construct, one strain showing a PCR reaction diagnostic for correct integration was analyzed by crossing to strain JB12 and dissecting tetrads. This revealed a 2:2 segregation of G418 resistance in both cases, indicating that each marker had integrated at a single site in the genome. Strains JB111, JB112, and JB115 are segregants from these crosses.

\section{Generation of Pom1p-specific antibodies}

A 878-bp fragment of pom1 (codons 283-575) with Bcll and EcoRI sites at the upstream end and Bcll and Xhol sites at the downstream end was PCR amplified by use of the Expand System with primers $5^{\prime}$-CTATTCCTCCTAATATGATCAATGAATTCGATCACCAACATCCTAAAGCAAATATATC-3' and 5'-CATTTGAAGACTCGAGAGTGATCAAAGGCTGTAATGATTCACTCGTATCAG-3' (restriction sites underlined). The PCR product was digested with EcoRI and Xhol or with Bcll and cloned into the corresponding sites of plasmids PM AL-C2 (N ew England Biolabs) and pGEX3X (Pharmacia), respectively, to generate fusions of Pomlp to $\mathrm{M}$ alE and glutathione S-transferase (GST). The Pomlp fusion proteins were expressed in Escherichia coli strain $\mathrm{DH} 5 \alpha$ (Life Technologies). Attempts to purify the GST fusion protein with glutathione-agarose beads resulted in extensive degradation. Therefore, full-length GSTPomlp was obtained by separation of whole-cell extracts by SDS-PAGE. The gel slices containing the fusion protein were used to inject two rabbits by use of standard procedures (Cocalico Biologicals). Antibodies were affinity purified as described previously (Pringle et al. 1991) by use of nitrocellulose strips containing MalE-Pomlp and elution with $4.5 \mathrm{M} \mathrm{M} \mathrm{gCl}_{2}$.

\section{Microscopy}

Cells were observed by fluorescence microscopy using a Nikon Microphot SA microscope with a $60 \times$ Plan-apo objective. F-actin was stained with rhodamine-conjugated phalloidin (Sigma) as described by Bal asubramanian et al. (1997). To visual ize actin together with septa and nuclear DNA, cells were stained with rhodamine-phal loidin as described by Alfa et al. (1993) with the addition of $50 \mu \mathrm{g} / \mathrm{ml} \mathrm{Calcofluor}$ (Sigma) to the staining solu- tion. Cells were then examined in mounting medium containing $0.05 \mu \mathrm{g} / \mathrm{ml}$ bisBenzimide (Sigma). Birth scars were visualized by staining with Calcofluor as described by Verde et al. (1995). To visualize growth zones by use of FITC-conjugated Bandei raea simplicifolia lectin (M ay and Mitchison 1986), cells grown in EMM medium were resuspended in EMM plus $5 \mu \mathrm{g} /$ $\mathrm{ml} \mathrm{FITC-lectin} \mathrm{(Sigma,} \mathrm{L-9381)} \mathrm{for} 5 \mathrm{~min}$, washed twice in EM M , and incubated further in EMM in the dark for 30-60 min. Cells were then counterstained with Calcofluor $(1 \mathrm{mg} / \mathrm{ml}$ in ice-cold $1 \% \mathrm{~N} \mathrm{aCl}$ ) and observed.

To visual ize 3HA-tagged Pomlp by immunofluorescence, exponentially growing cells were fixed with $3.8 \%$ formaldehyde for 30 min in EM M medium, washed threetimes with PEM (100 mM N a-PIPES at pH 6.9, 1 mm EGTA, $1 \mathrm{~mm} \mathrm{M} \mathrm{gSO}_{4}$ ) (Hagan and Hyams 1988), and digested for $15 \mathrm{~min}$ at $30^{\circ} \mathrm{C}$ in PEM plus $1 \mathrm{M}$ sorbitol (PEM S) containing $0.5 \mathrm{mg} / \mathrm{ml}$ yeast lytic enzyme (ICN Biochemicals) and $0.1 \mathrm{mg} / \mathrm{ml}$ lysing enzymes (Sigma, L2773). Cells were washed once in PEMS plus $1 \%$ Triton X-100 and three times in PEM, resuspended in PEM BAL (PEM plus $0.1 \mathrm{M}$ L-Iysine, $1 \%$ BSA, $0.1 \%$ sodium azide), and shaken gently for 30 min. Cells were then applied to multiwell slides as described previously (Pringle et al. 1991) and incubated for $16 \mathrm{hr}$ at room temperature with the monoclonal HA11 antibody (Berkel ey Antibody Co.) diluted 1:200 in PEMBAL. After three 10-min washes with PEMBAL, FITC-tagged anti-mouse-IgG secondary antibodies (Jackson ImmunoResearch) diluted 1:200 in PEMBA L were applied for $4 \mathrm{hr}$ at room temperature. Cells were again washed three times with PEM BAL and then observed in mounting medium as described above. For double staining of Pomlp and actin, cells were treated with $-20^{\circ} \mathrm{C}$ methanol and acetone for $6 \mathrm{~min}$ and $30 \mathrm{sec}$, respectively, before incubation with the primary antibodies. Goat antibodies to S. cerevisiae actin (a gift from J. Cooper, Washington University, St. Louis, MO) were diluted 1:100 in PEM BAL, applied to the cells together with the HAll antibody, and detected by use of TRITC-tagged anti-goatIgG antibodies (Jackson ImmunoResearch) diluted 1:200 in PEM BAL and applied to the cells together with the FITC-tagged anti-mouse-IgG antibodies. Photographs of double-stained cells were taken using a Zeiss laser-scanning confocal microscope with a $63 \times$ objective and were analyzed by Zeiss and Adobe Photoshop software.

Immunofluorescence with anti-Pomlp antibodies followed the same protocol as just described. Affinity-purified antibodies were diluted 1:20 to 1:50 in PEMBAL and detected by use of FITC-conjugated anti-rabbit-IgG secondary antibodies (Jackson ImmunoResearch) diluted $1: 200$ in PEMBAL. To visualize Tealp, cells were fixed with $-70^{\circ} \mathrm{C}$ methanol for $30 \mathrm{~min}$, stained with anti-Tealp antibodies (M ata and N urse 1997) diluted 1:30 in PEMBAL, and detected with anti-rabbit-IgG antibodies as described above. To stain microtubules with the monoclonal anti-tubulin antibody TAT1 (Woods et al. 1989), cells were fixed using a combination of formal dehyde and glutaral dehyde and then treated with sodium borohydride as described previously (Hagan and Hyams 1988). TAT 1 was diluted 1:10 in PEMBAL, and FITC-tagged anti-mouse-lgG secondary antibodies were used as described above.

To observe GFP-tagged Pomlp in living cells, cells were grown to early exponential phase $\left(<5 \times 10^{6} \mathrm{cells} / \mathrm{ml}\right)$, mounted on a thin layer of EM M containing $25 \%$ gelatin, seal ed under a coverslip with Valap (1:1:1 vaseline/lanolin/paraffin), and observed at room temperature using a Nikon FXA microscope equipped with a Hamamatsu cooled-CCD camera and an A po $60 X / 1.4$ n.a. objective in combination with a $2 \times$ Optivar (Salmon et al. 1994). Images were collected every 1-5 min by a 3-sec exposure of 490-nm light and anal yzed using the U niversal M etamorph Imaging System. For some time-lapse series of the 
GFP-tagged cells, digitally enhanced DIC images were recorded in parallel (Yeh et al. 1995; Shaw et al. 1997). Time-lapse studies of non-GFP-tagged cells growing on YE medium were recorded by DIC with the same procedure.

\section{Acknowledgments}

We thank F. Chang, J. Cooper, B. Edgar, J. Fikes, K. Gull, J. Kohli, M. Longtine, J. Mata, D. McCollum, A. McKenzie, P. Nurse, S. Parisi, P. Philippsen, V. Simanis, A. Wach, and P. Young for gifts of antibodies, plasmids, and strains; J. Adam, E. Y eh, T. Salmon, A. Steever, and J. Wu for assistance with some experiments; J. Mata and P. N urse for communicating results prior to publication; S. Whitfield for superb photographic services; and O. Al-Awar, E. Bi, D. Brunner, M. Longtine, J. Mata, D. M cCollum, P. N urse, and K. Sawin for valuable discussions and/or critical reading of the manuscript. This work was supported by $\mathrm{N}$ ational Institutes of $\mathrm{H}$ eal th grant GM 31006. J.B. was supported by fellowships from the Swiss National Science Foundation and the Ciba-Geigy-Jubiläums-Stiftung.

The publication costs of this article were defrayed in part by payment of page charges. This article must therefore be hereby marked "advertisement" in accordance with 18 USC section 1734 solely to indicate this fact.

\section{References}

Adachi, Y., T. Toda, O. Niwa, and M. Yanagida. 1986. Differential expressions of essential and nonessential $\alpha$-tubulin genes in Schizosaccharomyces pombe. Mol. Cell. Biol. 6: 2168-2178.

Alfa, C., P. Fantes, J. Hyams, M. M cLeod, and E. Warbrick. 1993. Experiments with fission yeast. Cold Spring Harbor Laboratory Press, Cold Spring Harbor, NY.

Ayscough, K.R., J. Stryker, N. Pokala, M. Sanders, P. Crews, and D.G. Drubin. 1997. High rates of actin filament turnover in budding yeast and roles for actin in establishment and maintenance of cell polarity revealed using the actin inhibitor latrunculin-A. J. Cell Biol. 137: 399-416.

Bähler, J., J.-Q. Wu, M.S. Longtine, N.G. Shah, A. M cKenzie III, A.B. Steever, A. Wach, P. Philippsen, and J.R. Pringle. 1998. Heterologous modules for efficient and versatile PCR-based gene targeting in Schizosaccharomyces pombe. Yeast (in press).

Bal asubramanian, M.K., D.M. Helfman, and S.M. Hemmingsen. 1992. A new tropomyosin essential for cytokinesis in the fission yeast S. pombe. Nature 360: 84-87.

Bal asubramanian, M.K., B.R. Hirani, J.D. Burke, and K.L. Gould. 1994. The Schizosaccharomyces pombe $\mathrm{cdc}^{+}$gene encodes a profilin essential for cytokinesis. J. Cell Biol. 125: 12891301.

Balasubramanian, M.K., D. McCollum, and K.L. Gould. 1997. Cytokinesis in the fission yeast Schizosaccharomyces pombe. Methods Enzymol. 283: 494-506.

Chang, F. and P. N urse. 1996. How fission yeast fission in the middle. Cell 84: 191-194.

Chang, F., A. Woollard, and P. N urse. 1996. Isolation and characterization of fission yeast mutants defective in the assembly and placement of the contractile actin ring. J. Cell Sci. 109: 131-142.

Ding, R., R.R. West, M. M orphew, B.R. Oakley, and J.R. M clntosh. 1997. The spindle pole body of Schizosaccharomyces pombe enters and leaves the nuclear envelope as the cell cycle proceeds. Mol. Biol. Cell 8: 1461-1479.

Drubin, D.G. and W.J. Nelson. 1996. Origins of cell polarity.
Cell 84: 335-344.

Edamatsu, M. and Y.Y. Toyoshima. 1996. Isolation and characterization of pos mutants defective in correct positioning of septum in Schizosaccharomyces pombe. Zool. Sci. 13: 235239.

Fankhauser, C. and V. Simanis. 1993. The Schizosaccharomyces pombe cdc14 gene is required for septum formation and can also inhibit nuclear division. Mol. Biol. Cell. 4: 531-539.

Fikes, J.D., D.M. Becker, F. Winston, and L. Guarente. 1990. Striking conservation of TFIID in Schizosaccharomyces pombe and Saccharomyces cerevisiae. Nature 346: 291-294.

Garrett, S. and J. Broach. 1989. Loss of Ras activity in Saccharomyces cerevisiae is suppressed by disruptions of a new kinase gene, YAK1, whose product may act downstream of the cAM P-dependent protein kinase. Genes \& Dev. 3: 13361348.

Hagan, I.M . and J.S. Hyams. 1988. The use of cell division cycle mutants to investigate the control of microtubule distribution in the fission yeast Schizosaccharomyces pombe. J. Cell Sci. 89: 343-357.

Hanks, S.K. and T. Hunter. 1995. The eukaryotic protein kinase superfamily: Kinase (catalytic) domain structure and classification. FASEB J. 9: 576-596.

Heim, R., A.B. Cubitt, and R.Y. Tsien. 1995. Improved green fluorescence. Nature 373: 663-664.

Hiraoka, Y., T. Toda, and M. Y anagi da. 1984. The NDA3 gene of fission yeast encodes $\beta$-tubulin: A cold-sensitive nda3 mutation reversibly blocks spindle formation and chromosome movement in mitosis. Cell 39: 349-358.

Hoffman, C.S. and F. Winston. 1987. A ten-minute DNA preparation from yeast efficiently releases autonomous plasmids for transformation of Escherichia coli. Gene 57: 267-272.

Jimenez, J. and J. Oballe. 1994. Ethanol-hypersensitive and ethanol-dependent $\mathrm{cdc}^{-}$mutants in Schizosaccharomyces pombe. Mol. Gen. Genet. 245: 86-95.

Jochová, J., I. Rupeš, and E. Streibl ová. 1991. F-actin contractile rings in protoplasts of the yeast Schizosaccharomyces. Cell Biol. Int. Rep. 15: 607-610.

Keeney, J.B. and J.D. Boeke. 1994. Efficient targeted integration at leu1-32 and ura4-294 in Schizosaccharomyces pombe. Genetics 136: 849-856.

Kelly, T.J., G.S. Martin, S.L. Forsburg, R.J. Stephen, A. Russo, and P. N urse. 1993. The fission yeast $\mathrm{cdc} 18^{+}$gene product couples S phase to START and mitosis. Cell 74: 371-382.

Kentrup, H., W. Becker, J. Heukel bach, A. Wilmes, A. Schürmann, C. Huppertz, H. Kainulainen, and H.-G. Joost. 1996. Dyrk, a dual specificity protein kinase with unique structural features whose activity is dependent on tyrosine residues between subdomains VII and VIII. J. Biol. Chem. 271: 3488-3495.

Kitayama, C., A. Sugimoto, and M. Yamamoto. 1997. Type II myosin heavy chain encoded by the myo2 gene composes the contractile ring during cytokinesis in Schizosaccharomyces pombe. J. Cell Biol. 137: 1309-1319.

Kohli, J., H. Hottinger, P. Munz, A. Strauss, and P. Thuriaux. 1977. Genetic mapping in Schizosaccharomyces pombe by mitotic and meiotic analysis and induced haploidization. Genetics 87: 471-489.

Lehmann, R. 1995. Cell-cell signaling, microtubules, and the loss of symmetry in the Drosophila oocyte. Cell 83: 353356.

Leupold, U. 1970. Genetical methods for Schizosaccharomyces pombe. Methods Cell Physiol. 4: 169-177.

Marks, J. and J.S. Hyams. 1985. Localization of F-actin through the cell division cycle of S. pombe. Eur. J. Cell Biol. 39: 2732. 
Marks, J., I.M. Hagan, and J.S. Hyams. 1986. Growth polarity and cytokinesis in fission yeast: The role of the cytoskeleton. J. Cell Sci. Suppl. 5: 229-241.

Mata, J. and P. N urse. 1997. teal and the microtubular cytoskeleton are important for generating global spatial order within the fission yeast cell. Cell 89: 939-949.

Maundrell, K. 1993. Thiamine-repressible expression vectors pREP and pRIP for fission yeast. Gene 123: 127-130.

May, J.W. and J.M. Mitchison. 1986. Length growth in fission yeast cells measured by two novel techniques. Nature 322: 752-754.

McCollum, D., M.K. Bal asubramanian, L.E. Pelcher, S.M. Hemmingsen, and K.L. Gould. 1995. Schizosaccharomyces pombe $c d c 4^{+}$gene encodes a novel EF-hand protein essential for cytokinesis. J. Cell Biol. 130: 651-660.

McCollum, D., A. Feoktistova, M. M orphew, M. Bal asubramanian, and K.L. Gould. 1996. The Schizosaccharomyces pombe actin-related protein, Arp3, is a component of the cortical actin cytoskeleton and interacts with profilin. EMBO J. 15: 6438-6446.

Mitchison, J.M. and P. N urse. 1985. Growth in cell length in the fission yeast Schizosaccharomyces pombe. J. Cell Sci. 75: 357-376.

Moreno, S., A. Klar, and P. Nurse. 1991. Molecular genetic analysis of fission yeast Schizosaccharomyces pombe. Methods Enzymol. 194: 795-823.

Nurse, P. 1994. Fission yeast morphogenesis-posing the problems. Mol. Biol. Cell 5: 613-616.

N urse, P., P. Thuriaux, and K. N asmyth. 1976. Genetic control of the cell division cycle in the fission yeast Schizosaccharomyces pombe. Mol. Gen. Genet. 146: 167-178.

Pichová, A., S.D. Kohlwein, and M. Yamamoto. 1995. N ew arrays of cytoplasmic microtubules in the fission yeast Schizosaccharomyces pombe. Protoplasma 188: 252-257.

Pringle, J.R., A.E.M. Adams, D.G. Drubin, and B.K. Haarer. 1991. Immunofluorescence methods for yeast. Methods Enzymol. 194: 565-602.

Pringle, J.R., E. Bi, H.A. Harkins, J.E. Zahner, C. De Virgilio, J. Chant, K. Corrado, and H. Fares. 1995. Establishment of cell polarity in yeast. Cold Spring Harbor Symp. Quant. Biol. 60: 729-744.

Reymond, A., S. Schmidt, and V. Simanis. 1992. Mutations in the cdc10 start gene of Schizosaccharomyces pombe implicate the region of homology between cdc10 and SWI6 as important for p85 ${ }^{\mathrm{cdc} 10}$ function. Mol. Gen. Genet. 234: 449456.

Salmon, E.D., T. Inoué, A. Desai, and A.W. Murray. 1994. High resolution multimode digital imaging system for mitosis studies in vivo and in vitro. Biol. Bull. 187: 231-232.

Sambrook, J., E.F. Fritsch, and T. Maniatis. 1989. Molecular cloning: A laboratory manual. Cold Spring Harbor Laboratory Press, Cold Spring Harbor, NY.

Shaw, S.L., E. Yeh, K. Bloom, and E.D. Salmon. 1997. Imaging GFP-fusion proteins in Saccharomyces cerevisiae. Curr. Biol. 7: 701-704.

Smith, D.J., M.E. Stevens, S.P. Sudanagunta, R.T. Bronson, M. Makhinson, A.M. Watabe, T.J. O'Dell, J. Fung, H.-U.G. Weier, J.-F. Cheng, and E.M. Rubin. 1997. Functional screening of $2 \mathrm{Mb}$ of human chromosome 21q22.2 in transgenic mice implicates minibrain in learning defects associated with Down Syndrome. Nature Genetics 16: 28-36.

Snell, V. and P. N urse. 1993. Investigations into the control of cell form and polarity: The use of morphological mutants in fission yeast. Development (Suppl.) : 289-299.

- - . 1994. Genetic analysis of cell morphogenesis in fission yeast-a role for casein kinase II in the establishment of polarized growth. EMBO J. 13: 2066-2074.

Sohrmann, M., C. Fankhauser, C. Brodbeck, and V. Simanis. 1996. The $\mathrm{dmf} 1 / \mathrm{mid} 1$ gene is essential for correct positioning of the division septum in fission yeast. Genes $\&$ Dev. 10: 2707-2719.

Strome, S. 1993. Determination of cleavage planes. Cell 72: 3-6.

Tejedor, F., X.R. Zhu, E. Kaltenbach, A. Ackermann, A. Baumann, I. Canal, M. Heisenberg, K.F. Fischbach, and O. Pongs. 1995. minibrain: A new protein kinase family involved in postembryonic neurogenesis in Drosophila. Neuron 14: 287301.

Thuriaux, P., M. Sipiczki, and P.A. Fantes. 1980. Genetical analysis of a sterile mutant by protoplast fusion in the fission yeast Schizosaccharomyces pombe. J. Gen. Microbiol. 116: 525-528.

Umesono, K., T. Toda, S. Hayashi, and M. Yanagida. 1983. Two cell division cycle genes NDA2 and NDA3 of the fission yeast Schizosaccharomyces pombe control microtubular organization and sensitivity to anti-mitotic benzimidazole compounds. J. Mol. Biol. 168: 271-284.

Verde, F., J. Mata, and P. N urse. 1995. Fission yeast cell morphogenesis: Identification of new genes and analysis of their role during the cell cycle. J. Cell Biol. 131: 1529-1538.

Woods, A., T. Sherwin, R. Sasse, T.H. M acRae, A.J. Baines, and K. Gull. 1989. Definition of individual components within the cytoskeleton of Trypanosoma brucei by a library of monoclonal antibodies. J. Cell Sci. 93: 491-500.

Wright, A., K. M aundrell, W.-D. Heyer, D. Beach, and P. N urse. 1986. Vectors for the construction of gene banks and the integration of cloned genes in Schizosaccharomyces pombe and Saccharomyces cerevisiae. Plasmid 15: 156-158.

Yaffe, M.P., D. Harata, F. Verde, M. Eddison, T. Toda, and P. N urse. 1996. Microtubules mediate mitochondrial distribution in fission yeast. Proc. Natl. Acad. Sci. 93: 11664-11668.

Yeh, E., R.V. Skibbens, J.W. Cheng, E.D. Salmon, and K. Bloom. 1995. Spindle dynamics and cell cycle regulation of dynein in the budding yeast, Saccharomyces cerevisiae. J. Cell Biol. 130: 687-700.

Zahner, J.E., H.A. Harkins, and J.R. Pringle. 1996. Genetic analysis of the bipolar pattern of bud site selection in the yeast Saccharomyces cerevisiae. Mol. Cell. Biol. 16: 18571870. 


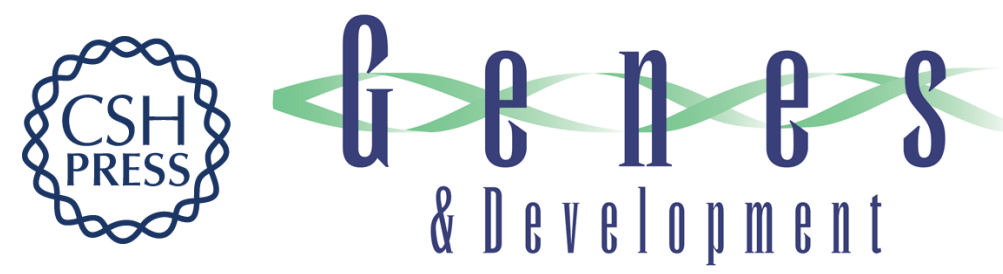

\section{Pom1p, a fission yeast protein kinase that provides positional information for both polarized growth and cytokinesis}

Jürg Bähler and John R. Pringle

Genes Dev. 1998, 12:

References This article cites 56 articles, 22 of which can be accessed free at:

http://genesdev.cshlp.org/content/12/9/1356.full.html\#ref-list-1

License

Email Alerting

Receive free email alerts when new articles cite this article - sign up in the box at the top

Service right corner of the article or click here.

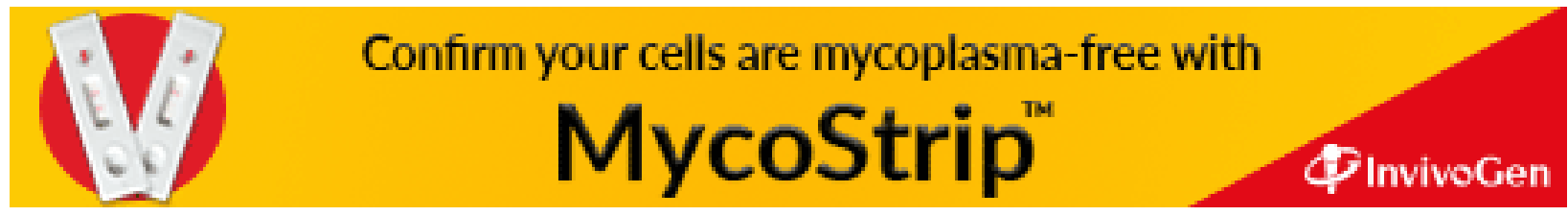

